\title{
The Alien Tort Statute and Article III
}

\author{
Curtis A. Bradley*
}

\section{TABLE OF CONTENTS}

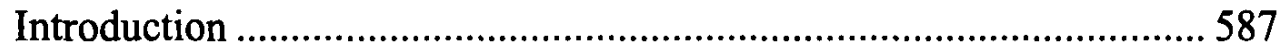

I. The Cause of Action Theory ...................................................592

II. Law of Nations as Federal Law? ..........................................597

III. Implementation of Alienage Jurisdiction ...............................619

IV. Suits by Ambassadors ..........................................................637

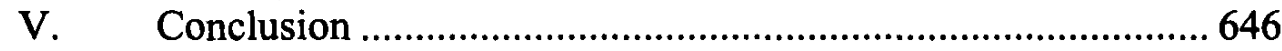

\section{INTRODUCTION}

In 1789, the First Congress enacted the First Judiciary Act, a statute that established the federal courts and regulated their jurisdiction and structure. Section 9 of the Act, which regulated the jurisdiction of the federal district courts, provided, among other things, that these courts "shall also have cognizance, concurrent with the courts of the several States, or the circuit courts, as the case may be, of all causes where an alien sues for a tort only in violation of the law of nations or a treaty of the United States." This alien tort provision has been recodified by Congress several times, with minor alterations, ${ }^{2}$ and is today commonly referred to as the "Alien Tort Statute" or, sometimes less accurately, the "Alien Tort Claims Act." In its current form, the Alien Tort Statute

* Professor of Law and Hunton \& Williams Research Professor, University of Virginia. For helpful comments and suggestions, I thank William Casto, Michael Collins, Barry Cushman, Bill Dodge, Martin Flaherty, John Harrison, Caleb Nelson, Mike Ramsey, John Rogers, Mark Weisburd, and Ted White. For excellent research assistance, I thank David Zetoony.

1. Judiciary Act, ch. 20, § 9, 1 Stat. 73, 77 (1789).

2. The Statute was modified in $\mathbf{1 8 7 3}$ to read: "The district courts shall have jurisdiction as follows: . . . Of all suits brought by any alien for a tort 'only' in violation of the law of nations, or of a treaty of the United States." REVISED STATUTES tit. 13, ch. 3, § 563, para. 16 (1873). It was slightly altered in a 1911 codification to read: "The district courts shall have original jurisdiction as follows: ... Of all suits brought by any alien for a tort only, in violation of the laws of nations or of a treaty of the United States." Act of March 3, 1911, ch. 231, § 24, 36 Stat. 1087, 1093 (1911). The current version of the Statute dates back to a 1948 revision of the Judicial Code. 
provides that the district courts "shall have original jurisdiction of any civil action by an alien for a tort only, committed in violation of the law of nations or a treaty of the United States."3

Although the Alien Tort Statute has been in existence for over two hundred years, it was an insignificant source of federal court jurisdiction during most of its history. Before 1980, jurisdiction had been upheld under this Statute in only two reported cases, one in 1795 and the other in $1961{ }^{4}$ The Statute was unsuccessfully invoked by plaintiffs as a basis for jurisdiction in only a modest number of additional reported cases. ${ }^{5}$ In 1975, the U.S. Court of Appeals for the Second Circuit, in an opinion by Judge Henry Friendly, referred to the Statute as an "old but little used section," and described it as "a kind of legal Lohengrin; although it has been with us since the first Judiciary Act ... no one seems to know whence it came." The court further cautioned (rather cryptically) that the section's reference to the law of nations "must be narrowly read if the section is to be kept within the confines of Article III [of the Constitution]."?

The obscurity of the Alien Tort Statute ended in 1980, with the Second Circuit's decision in Filartiga v. Pena-Irala. ${ }^{8}$ In Filartiga, the court construed the Alien Tort Statute as authorizing federal court jurisdiction over suits between non-U.S. citizens for violations of customary international law, the modern term for at least one branch of the law of nations.9 The court therefore allowed two Paraguayans to sue

3. 28 U.S.C. $\S 1350$ (2001).

4. See Adra v. Clift, 195 F. Supp. 857 (D. Md. 1961); Bolchos v. Darrel, 3 F. Cas. 810 (D.S.C. 1795) (No. 1607); see also Yen v. Kissinger, 528 F.2d 1194, 1202 n.13 (9th Cir. 1975) (suggesting, in a suit by Vietnamese citizens against U.S. officials, that jurisdiction under the Alien Tort Statute "may be available").

5. See O'Reilly de Camara v. Brooke, 209 U.S. 45 (1908); Anh v. Levi, 586 F.2d 625 (6th Cir. 1978); Benjamins v. British European Airways, 572 F.2d 913 (2d Cir. 1978); IIT v. Vencap, Ltd., 519 F.2d 1001 (2d Cir. 1975); Abiodun v. Martin Oil Service, Inc., 475 F.2d 142 (7th Cir. 1973); Khedivial Line, S.A.E. v. Seafarers' International Union, 278 F.2d 49 (2d Cir. 1960); Trans-Continental Investment Corp., S.A. v. Bank of the Commonwealth, 500 F. Supp. 565 (C.D. Cal. 1980); Cohen v. Hartman, 490 F. Supp. 517 (S.D. Fla. 1980); Valanga v. Metropolitan Life Ins. Co., 259 F. Supp. 324 (E.D. Pa. 1966); Damaskinos v. Societa Navigacion Interamericana, S.A., 255 F. Supp. 919 (S.D.N.Y. 1966); Lopes v. Schroder, 225 F. Supp. 292 (E.D. Pa. 1963); Upper Lakes Shipping Ltd. v. Int'l Longshoremen's Ass'n, 33 F.R.D. 348 (S.D.N.Y. 1963); Moxon v. The Fanny, 17 F. Cas. 942 (D. Pa. 1793).

6. IIT v. Vencap, Ltd., 519 F.2d 1001, 1015 (2d Cir. 1975).

7. Id.

8. 630 F.2d 876 (2d Cir. 1980).

9. Customary international law is the law of the international community that "results from a general and consistent practice of states followed by them from a sense of legal obligation." RESTATEMENT (THIRD) OF THE FOREIGN RELATIONS LAW OF THE UNITED STATES § 102(2) (1987); $c f$. STATUTE OF THE INT'L COURT OF JUSTICE, art. 38(1)(b), 59 Stat. 1031 (entered into force Oct. 24, 1945) (stating that the Court shall apply "international custom, as evidence of a general practice accepted as law"). 
a former Paraguayan official for the alleged torture and killing of their family member in Paraguay, conduct that the court concluded violated customary international human rights standards. The court reasoned that the suit satisfied the terms of the Alien Tort Statute because it was brought "by an alien," it was "for a tort," and it involved a "violation of the law of nations." 10 The court also concluded that federal court jurisdiction over the suit was consistent with Article III. Noting that the Supreme Court has held that claims based on federal common law "aris[e] under the ... laws ... of the United States" for purposes of statutory federal question jurisdiction, ${ }^{11}$ the court reasoned that suits involving violations of the law of nations similarly "aris[e] under ... the Laws of the United States" for purposes of Article III because "the law of nations ... has always been part of the federal common law."12

The Filartiga decision paved the way for international human rights litigation in U.S. courts. Since the decision, numerous lawsuits have been brought in the United States challenging human rights abuses around the world, ranging from political oppression in Ethiopia, to genocide and war crimes in Bosnia, to violence by the Guatemalan military. ${ }^{13}$ In addition, encouraged by a subsequent Second Circuit decision holding that state action is not always required for a violation of the law of nations, ${ }^{14}$ this litigation recently has expanded to include suits against multinational corporations, concerning alleged breaches of customary international law with respect to both human rights and environmental protection. ${ }^{15}$ Although not all of these Alien Tort Statute cases have been successful on the merits, a number of courts have accepted the Second Circuit's conclusion that the Statute gives the federal courts jurisdiction to hear suits between alien parties concerning human rights abuses committed outside the United States. To date, only the D.C. Circuit has seriously questioned this conclusion, and it did so in a splintered panel decision containing no majority opinion. ${ }^{16}$ Perhaps

10. Filartiga, 630 F.2d at 887 .

11. See Illinois v. Milwaukee, 406 U.S. 91, 98-100 (1972).

12. 630 F.2d at $885-86$.

13. See, e.g., Abebe-Jira v. Negewo, 72 F.3d 844 (11 th Cir. 1996); Kadic v. Karadzic, 70 F.3d 232 (2d Cir. 1995); Xuncax v. Gramajo, 886 F. Supp. 162 (D. Mass. 1995).

14. See Karadzic, 70 F.3d at 239.

15. See, e.g., Wiwa v. Royal Dutch Petroleum Co., 226 F.3d 88 (2d Cir. 2000); Beanal v. Freeport-McMoran, Inc., 197 F.3d 161 (5th Cir. 1999); Doe v. Unocal Corp., 110 F. Supp. 2d 1294 (C.D. Cal. 2000), appeal pending (9th Cir.).

16. See Tel-Oren v. Libyan Arab Republic, 726 F.2d 774 (D.C. Cir. 1984). One of the judges on the panel (Judge Edwards) asserted that the opinions by the other two judges (Judges Bork and Robb) were "fundamentally at odds" with Filartiga. Id. at 775. There is also some reasoning in a subsequent D.C. Circuit decision, Princz v. Federal Republic of Germany, 26 F.3d 1166 (D.C. Cir. 1994), that may be inconsistent with Filartiga. In Princz, the court suggested that a tort claim 
for that reason, the Supreme Court has so far declined to address the propriety of Filartiga and its progeny. ${ }^{17}$

In this Article, I explore the likely understanding of the First Congress regarding the Alien Tort Statute's relationship to Article III of the Constitution. Although there have been a number of thoughtful articles in recent years concerning the original meaning of the Alien Tort Statute, none of these articles has focused extensively on the Statute's relationship to Article III. ${ }^{18}$ Instead, these articles have speculated about the kinds of cases the First Congress might have had in mind when it used the phrase "tort only in violation of the law of nations." Framed this way, the inquiry is essentially unbounded: almost anything that happened in the pre-Constitutional period, or that was mentioned in the international law treatises of the time, or that could have been anticipated by the First Congress, is a potential candidate. It is not surprising, therefore, that these articles have reached wildly different conclusions concerning the scope of the Statute. Nor is it surprising that none of these articles seems to have come close to settling the historical question.

By focusing on the Statute's relationship with Article III, we may be able to limit the inquiry in a way that will produce a more definitive historical answer. In particular, I believe we can eliminate the

involving a violation of the law of nations does not arise under federal law for purposes of the general federal question jurisdiction statute, 28 U.S.C. § 1331. See id. at 1176. The federal question statute has been construed to contain a well-pleaded complaint requirement not mandated by Article III. See Franchise Tax Bd. v. Construction Laborers Vacation Trust, 463 U.S. 1 (1983); Louisville \& Nashville Railroad Co. v. Mottley, 211 U.S. 149 (1908). Nevertheless, it is not clear how a claim for a tort in violation of the law of nations could arise under the "Laws of the United States" for purposes of Article III, as Filartiga held, and not arise under the "laws of the United States" for purposes of the federal question statute.

17. The Supreme Court has considered one Alien Tort Statute case since Filartiga. See Argentine Republic v. Amerada Hess Shipping Corp., 488 U.S. 428 (1989). In that case, two Liberian companies sued the Republic of Argentina to recover damages suffered as a result of Argentina's destruction of an oil tanker during the Falklands War, allegedly in violation of the law of nations. The Supreme Court held that, because the suit was against a foreign state, it was governed exclusively by the Foreign Sovereign Immunities Act, 28 U.S.C. $\S \S 1330,1602-11$, and could not be maintained under the Alien Tort Statute.

18. See, e.g., Anne-Marie Burley, The Alien Tort Statute and the Judiciary Act of 1789: A Badge of Honor, 83 AM. J. INT'L L. 461 (1989); William R. Casto, The Federal Courts' Protective Jurisdiction Over Torts Committed in Violation of the Law of Nations, 18 CONN. L. REV. 467 (1986); Anthony D'Amato, The Alien Tort Statute and the Founding of the Constitution, 82 AM. J. INT'L L. 62 (1988); William S. Dodge, The Historical Origins of the Alien Tort Statute: A Response to the "Originalists," 19 HASTINGS INT'L \& COMP. L. REV. 221 (1996); Kenneth C. Randall, Federal Jurisdiction Over International Law Claims: Inquiries into the Alien Tort Statute, 18 N.Y.U. J. INr'L L. \& POL. 1 (1985); John M. Rogers, The Alien Tort Statute and How Individuals "Violate" International Law, 21 VAND. J. TRANSNAT'L L. 47 (1988); Joseph Modeste Sweeney, A Tort Only in Violation of the Law of Nations, 18 HASTINGS INT'L \& COMP. L. REV. 445 (1995). 
possibility that the First Congress thought that suits under the Alien Tort Statute for violations of the law of nations would have been "Cases... arising under ... the Laws of the United States" for purposes of Article III. As I will show, the First Congress did not intend in the Alien Tort Statute to create a federal statutory cause of action. Nor did it believe that the "Laws of the United States" in Article III encompassed the law of nations. As a result, the federal question construction of the Statute adopted in Filartiga and its progeny is wrong, at least as a matter of original statutory intent.

Once this Article III possibility is eliminated, suits brought under the Alien Tort Statute for violations of the law of nations, to be constitutional, would have to fall either within admiralty jurisdiction or within one of Article III's party-based grants of jurisdiction (such as alienage, suits against U.S. states, suits against the U.S. government, or suits affecting ambassadors). While it is possible that the First Congress had a combination of these possibilities in mind, there is little evidence to that effect. Rather, as I will show, the evidence suggests that the law of nations portion of the Alien Tort Statute was intended simply to implement Article III alienage jurisdiction. ${ }^{19}$ If so, then the First Congress either mistakenly believed that Article III alienage jurisdiction extended to any suit involving an alien, even suits between aliens concerning non-federal claims, or it implicitly intended to limit the Alien Tort Statute to situations in which at least one of the defendants was a U.S. citizen. There is evidence to support both of these possibilities. Nevertheless, I will argue that the weight of the evidence supports the latter possibility: the First Congress implicitly intended to limit the Alien Tort Statute to suits involving at least one U.S. citizen defendant.

The Alien Tort Statute, under this construction, authorized federal court jurisdiction over certain sensitive disputes between aliens and U.S. citizens, without regard to the $\$ 500$ amount in controversy limitation generally imposed by the First Congress on alienage jurisdiction. As I will explain, this construction of the Statute is supported by the text and structure of the First Judiciary Act, the legislative history and correspondence relating to the Act, and early scholarly commentary. It is also consistent with other materials that scholars have linked to the Statute, including a 1781 resolution of the Continental Congress that

19. Alienage jurisdiction extends to "Controversies... between a State, or the Citizens thereof, and foreign States, Citizens or Subjects." U.S. CoNST. art. III, § 2, cl. l. Although this is the first Article to present a full-fledged defense of an alienage jurisdiction construction of the Statute, earlier arguments in favor of this construction can be found in Arthur M. Weisburd, The Executive Branch and International Law, 41 VAND. L. REV. 1205, 1223-26 (1988). 
recommended that states take certain measures to address violations of the law of nations. In addition, this construction makes sense from the perspective of the law of international responsibility in 1789. Under that law, the United States generally would not have been responsible for torts committed by one alien against another, but it would have been responsible for certain torts committed by its citizens against aliens, such as torts that violated the international laws of neutrality. Scholars have missed this construction of the Statute because they have assumed that the Statute was designed, at least in part, to respond to two preconstitutional incidents involving ambassadorial protection, especially an incident involving an assault by a foreign citizen on a foreign ambassador. In fact, both the Constitution and the First Congress addressed those incidents in ways unrelated to the Statute.

\section{THE CAUSE OF ACTION THEORY}

One way of harmonizing the Alien Tort Statute with Article III would be to construe the Alien Tort Statute as not only granting jurisdiction but also creating a federal statutory cause of action, such that suits brought under the Alien Tort Statute would arise under federal statutory law for purposes of Article III. It is worth noting that this is not how the court in Filartiga construed the Statute. Rather, for purposes of its analysis, the court "construe[d] the Alien Tort Statute, not as granting new rights to aliens, but simply as opening the federal courts for adjudication of the rights already recognized by international law."20 Nevertheless, in several decisions after Filartiga, courts have expressed the view that the Alien Tort Statute both grants subject matter jurisdiction and creates a statutory cause of action. ${ }^{21}$ Moreover, human rights advocates now commonly refer to the Statute as the "Alien Tort

20. Filartiga v. Pena-Irala, 630 F.2d 876, 887 (2d Cir. 1980).

21. See, e.g., Hilao v. Estate of Marcos, 25 F.3d 1467, 1474-75 (9th Cir. 1994); Xuncax v. Gramajo, 886 F. Supp. 162, 179 (D. Mass. 1995); see also Tel-Oren v. Libyan Arab Republic, 726 F.2d 774, 780 (Edwards, J., concurring) (asserting that "section 1350 itself provides a right to sue for alleged violations of the law of nations"). In adopting the cause of action construction of the Statute, the Ninth Circuit appears to have been under the erroneous belief that the Second Circuit had already adopted this construction in Filartiga. See Hilao, 25 F.3d at 1475 ("We thus join the Second Circuit [in Filartiga] in concluding that the Alien Tort Act, 28 U.S.C. $\$ 1350$, creates a cause of action ...."). A somewhat different construction of the Alien Tort Statute, endorsed by one circuit court, is that the Statute delegates to the federal courts the power to fashion federal common law remedies to address violations of the law of nations. See Abebe-Jira v. Negewo, 72 F.3d 844, 847-48 (11th Cir. 1996). As Professor Collins explains, the First Congress almost certainly did not intend that construction. See Michael G. Collins, The Diversity Theory of the Alien Tort Statute, 42 VA. J. IN T'L L. 649, 671-74 (2002); see also Curtis A. Bradley \& Jack L. Goldsmith, The Current Illegitimacy of International Human Rights Litigation, 66 FORDHAM L. REV. 319, 358-59 (1997). 
Claims Act," a title suggesting that the Statute is more than just a jurisdictional provision.

Whatever one may think of this construction from a contemporary perspective, ${ }^{22}$ it is very unlikely that the First Congress intended it. Indeed, in the most thorough historical analysis of the Alien Tort Statute to date, Professor William Casto. refers to this cause of action construction as "simply frivolous." ${ }^{23}$ As noted above, the Statute originated as a clause in Section 9 of the First Judiciary Act. This Act, which was entitled "An Act to establish the Judicial Courts of the United States," was designed to regulate the structure and jurisdiction of the federal courts, not rights to relief. Consistent with this design, Section 9 of the Act contains a list of the cases that could be heard in the district courts and does not mention the standards of liability that would govern those cases. As Representative Fisher Ames stated in the House debates on the Judiciary Act, "there is a substantial difference between the jurisdiction of the court, and the rules of decision."24

Furthermore, the alien tort provision in Section 9 was only onesentence long, and it made no reference to damages or any other remedies. Instead, it referred to the "cognizance" of the district courts, which, as Professor Casto has documented, was a term of art in 1789, "referring to a court's power to try a case."25 The word "cognizance" is used in Section 11 of the Judiciary Act, for example, to refer to circuit court authority to hear diversity cases between U.S. citizens, a provision that no one thought created a statutory cause of action. As Casto has further noted, the First Congress used very different language when it created causes of action, such as language referring specifically to a

22. For discussion of some of the contemporary problems associated with construing the Alien Tort Statute as creating a statutory cause of action, see Curtis A. Bradley, Customary International Law and Private Rights of Action, 1 CHI. J. INT'L L. 421, 425 (2000), and Bradley $\&$ Goldsmith, supra note 21 , at 357-63.

23. Casto, supra note 18, at 479-80; see also JOHN M. ROGERS, INTERNATIONAL LAW AND UNITED STATES LAW 113-14 (1999) (noting that "this provision by its terms is no more than a grant of subject matter jurisdiction to the federal courts").

24. 11 DOCUMENTARY HISTORY OF THE FIRST FEDERAL CONGRESS 1357 (Charlene Bangs Bickford et al. eds., 1992) (remarks of Fisher Ames on Aug. 29, 1789); cf. Montana-Dakota Util. Co. v. Northwestern Pub. Serv. Co., 341 U.S. 246, 249 (1951) (noting that "[t]he Judicial Code, in vesting jurisdiction in the District Courts, does not create causes of action, but only confers jurisdiction to adjudicate those arising from other sources which satisfy its limiting provisions").

25. Casto, supra note 18, at 479; see, e.g., 3 WILLIAM BLACKSTONE, COMMENTARIES ON THE LAWS OF ENGLAND 42 (1768) (stating that the court of the King's bench "takes cognizance both of criminal and civil causes"); THE FEDERALIST NO. 80, at 475, 476 (Alexander Hamilton) (Clinton Rossiter ed., 1961) ("[T]he federal judiciary ought to have cognizance of all causes in which the citizens of other countries are concerned."); THE FEDERALIST NO. 81, supra, at 481, 488 (Alexander Hamilton) (referring to the Article III jurisdiction of the lower federal courts as "cases of federal cognizance"). 
right to recover damages. For example, in enacting a copyright statute, the First Congress provided that infringers of copyrights would be "liable to suffer and pay to the said author or proprietor all damages occasioned by such injury, to be recovered by a special action on the case founded upon this act, in any court having cognizance thereof.",26 Furthermore, ever since the Alien Tort Statute was first recodified in 1873 , it has contained the word "jurisdiction" instead of "cognizance," and there has never been any suggestion that this change in language was intended to alter the scope of the Statute. ${ }^{27}$

In addition, the First Congress likely would have thought it improper to regulate by statute the conduct of foreign citizens on foreign soil, in the way that the post-Filartiga decisions contemplate. While it was understood that courts might in some cases apply foreign law to adjudicate foreign disputes, ${ }^{28}$ prescriptive jurisdiction (the power of a nation to apply its laws to regulate conduct) was viewed at that time as highly territorial. An influential Dutch scholar, Ulrich Huber, had written in the 1600s that, "The laws of each state have force within the limits of that government and bind all subjects to it, but not beyond."29 Echoing Huber and subsequent commentators, Joseph Story would later explain in his conflict of laws treatise that "no state or nation can, by its laws, directly affect, or bind ... persons not resident therein," because to do so "would be wholly incompatible with the equality and exclusiveness of the sovereignty of any nation.".30 A 1795 Attorney General opinion that referred to the Alien Tort Statute similarly concluded that the United States' ability to regulate tortious conduct abroad was sharply limited. ${ }^{31}$ And early Supreme Court decisions

26. Act of May 31, 1790, ch. 15, $\S 6,1$ Stat. 124, 125-26 (1790).

27. In commenting on this Article, Professors Collins and Dodge both appear to agree with me that the Alien Tort Statute does not create a statutory cause of action. See Collins, supra note 21, at 671 n.105; William S. Dodge, The Constitutionality of the Alien Tort Statute: Some Observations on Text and Context, 42.VA. J: INT'L L. 687, 690 (2002).

28. See, e.g., THE FEDERALIST No. 82, supra note 25, at 491, 493 (Alexander Hamilton) ("The judiciary power of every government looks beyond its own local or municipal laws, and in civil cases lays hold of all subjects of litigation between parties within its jurisdiction, though the causes of dispute are relative to the laws of the most distant part of the globe. Those of Japan, not less than of New York, may furnish the objects of legal discussion to our courts."); 1 ST. GEORGE TUCKER, BLACKSTONE'S COMMENTARIES: WITH NOTES OF REFERENCE, TO THE CONSTITUTION AND LAWS OF THE FEDERAL GOVERNMENT OF THE UNITED STATES app. at 421 (1803) (noting that in diversity cases the rule of decision would be based on "the municipal law of the place where the cause of controversy arises, whether that be one of the United States, or Great Britain, France, Spain, Holland, Hamburg, or any other country").

29. Ulrich Huber, De Conflictu Legum Diversarum In Diversis Imperiis, cited and quoted in Ernest G. Lorenzen, Huber's De Conflictu Legum, 13 ILL. L. REV. 375, 376 \& app. at 403 (1919).

30. JOSEPH STORY, COMMENTARIES ON THE CONFLICT OF LAWS 21 (1834).

31. See 1 Op. Att'y Gen. 57 (1795). This opinion is discussed in greater detail below, see 
adhered to this view, and thus presumed that federal statutes did not apply to the conduct of foreign citizens outside the United States. ${ }^{32}$ There is no reason to think that the drafters of the First Judiciary Act had a different view. Indeed, Oliver Ellsworth, the principal draftsman of the Act, made clear after he became Chief Justice that he did not believe that the United States could regulate interactions between foreign citizens on foreign soil. ${ }^{33}$

More importantly, as explained more fully in the next Part, there would have been no reason for the First Congress to create a federal statutory cause of action for torts in violation of the law of nations. The law of nations was considered at that time to be part of the general common law, which could be applied by courts in the absence of controlling positive law to the contrary. ${ }^{34}$ Thus, "American courts resorted to this general body of preexisting law to provide the rules of decision in particular cases without insisting that the law be attached to any particular sovereign." ${ }^{.35}$ Although a dispute developed in the 1790s concerning the ability of federal courts to issue criminal sanctions to address breaches of the law of nations, there was little dispute in 1789 that courts with proper jurisdiction could issue civil remedies to enforce this law. They routinely did so, for example, in prize and other admiralty cases, in both the pre- and post-constitutional periods. ${ }^{36}$ As a

infra text accompanying notes 210-11.

32. See, e.g., The Apollon, 22 U.S. (9 Wheat.) 362, 370 (1824) ("The laws of no nation can justly extend beyond its own territories, except so far as regards its own citizens."); Rose v. Himely, 8 U.S. (4 Cranch) 241,279 (1807) ("It is conceded that the legislation of every country is territorial; that beyond its own territory, it can only affect its own subjects or citizens."); see also United States v. Palmer, 16 U.S. (3 Wheat.) 610, 632-33 (1818) (holding that general statutory language should not be construed to apply to the conduct of foreign citizens outside the United States).

33. See Letter from Chief Justice Ellsworth to Jonathan Trumbull (Mar. 13, 1796) (George Washington Papers, Library of Congress) (stating that treaties are needed in addition to federal statutes because federal statutes cannot regulate in the jurisdiction of other countries), cited in Casto, supra note 18 , at $485-86 \mathrm{n} .97$. The fact that the statutory cause of action would relate to international law would not eliminate the extraterritoriality problem, since U.S. law would still be creating the right to sue. See Collins, supra note 21, at 673-74.

34. See Bradford R. Clark, Federal Common Law: A Structural Reinterpretation, 144 U. PA. L. REV. 1245, 1276-85 (1996); Stewart Jay, The Status of the Law of Nations in Early American Law, 42 VAND. L. REV. 819 (1989); see also Beth Stephens, The Law of Our Land: Customary International Law as Federal Low After Erie, 66 FORDHAM L. REV. 393, $410-12$ (1997).

35. William A. Fletcher, The General Common Law and Section 34 of the Judiciary Act of 1789: The Example of Marine Insurance, 97 HARV. L. REV. 1513, 1517 (1984).

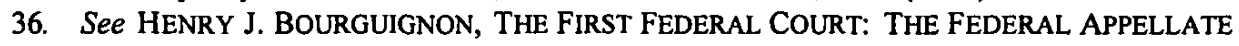
PRIZE COURT OF THE AMERICAN REVOLUTION, 1775-1787, at ch. VII (1977) (pre-constitutional period); G. EdWard White, THe Marshall COURT and Cultural Change, 1815-35, at ch. XIII (1988) (post-constitutional period); see also The Marianna Flora, 24 U.S. (11 Wheat.) 1, 41 (1826) (holding that a private, unauthorized attack by an armed vessel "may be punished by all the penalties which the law of nations can properly administer"); Thompson v. The Catharina, 23 
result, for those situations in which the law of nations in 1789 regulated tortious conduct, the First Congress would not have perceived a need to supplement this law with a federal statutory cause of action.

The only "historical" support for the cause of action construction of the Alien Tort Statute comes from an Attorney General opinion issued in $1907 .{ }^{37}$ In that opinion, the then-Attorney General, Charles J. Bonaparte, discusses the remedies that Mexican citizens might have for an American company's diversion of water from the Rio Grande, in violation of a treaty between the United States and Mexico. Bonaparte states that he is "of the opinion that existing statutes provide a right of action and a forum." ${ }^{38} \mathrm{He}$ then proceeds to quote from both the Alien Tort Statute and the general alienage jurisdiction statute. After quoting these two statutes, Bonaparte states, "I repeat that the statutes thus provide a forum and a right of action." " As Professor Casto has noted, Bonaparte's references to a "right of action" were probably "a sloppy reference to the federal courts' jurisdiction and not to the existence of a statutory cause of action." ${ }^{940}$ Otherwise, Bonaparte would appear to be suggesting that the general alienage jurisdiction statute also creates a statutory cause of action, which no one contends. Moreover, in other parts of his opinion, there are suggestions that the cause of action will come, if at all, from international law. ${ }^{41}$ In any event, this opinion, issued 118 years after the enactment of the Alien Tort Statute, is not evidence of the First Congress's intent, and it contains only assertions, not analysis.

As readers familiar with this area of law know, Congress did create a statutory cause of action for certain violations of international law in the 1992 Torture Victim Protection Act. This statute provides that any individual who commits torture or "extrajudicial killing" under color of foreign law shall, "in a civil action, be liable for damages."

F. Cas. 1028 (D. Pa. 1795) (No. 13,949) (explaining sources of law in admiralty cases); GRANT GILMORE \& CHARLES L. BLACK, JR., THE LAW OF ADMIRALTY 41 (1957) ("II]t was assumed at first, and later expressly stated by all authorities, that those courts to which judicial jurisdiction over maritime cases was granted were thereby empowered and obligated to apply to such cases, in the absence of statute, the rules of the gencral maritime law.").

37. See 26 Op. Att'y Gen. 250 (1907). In his concurrence in Tel-Oren, Judge Edwards relied on this Attorney General opinion to support his claim that the Alien Tort Statute creates a statutory cause of action. See 726 F.2d at 780 (Edwards, J., concurring).

38. 26 Op. Att'y Gen., supra note 37, at 252 .

39. Id. at 253.

40. Casto, supra note 18 , at $478-79$ n.58.

41. See 26 Op. Att'y Gen., supra note 37, at 253 (stating that the success of the action "would depend upon whether the diversion of the water was an injury to substantial rights of citizens of Mexico under the principles of international law or by treaty, and could only be determined by judicial decision").

42. Torture Victim Protection Act of 1991, $\S 2(a)$, Pub. L. No. 102-256, 106 Stat. 73 
also defines torture and extrajudicial killing, imposes a ten-year statute of limitations, and requires exhaustion of local remedies. ${ }^{43}$ Obviously, this statute has no bearing on the First Congress's intent. It does further highlight, however, the difference in wording between a cause of action statute and a mere jurisdictional statute - a difference just as evident today as it was in 1789. ${ }^{44}$ This difference is also evident in recent legislation creating statutory causes of action with respect to terrorism. ${ }^{45}$ In sum, the First Congress did not intend in the Alien Tort Statute to create a federal statutory cause of action.

\section{LAW OF NATIONS AS FEDERAL LAW?}

Another possibility is that the First Congress believed that the law of nations was part of the "Laws of the United States" referred to in Article III, such that law of nations cases brought under the Statute would fall within Article III's "arising under" jurisdiction. This theory is certainly more plausible than the cause of action construction, but it too is wrong.

The starting point for analyzing this issue is, of course, the constitutional text. The text contains numerous references to one form of international law-treaties. Article I, Section 10 denies states the ability to enter into treaties. Article II grants the President the power to make treaties, with the advice and consent of two-thirds of the Senate. Article III grants the federal courts the power to hear cases arising under treaties. And Article VI states that treaties are part of the supreme law of the land. The constitutional text contains only one reference, however, to the law of nations: Article I, Section 8 grants Congress the power to "define and punish... Offences against the Law of Nations." constitutional Founders could have, but did not, list cases arising under the law of nations as one of the categories of cases within the Article III jurisdiction of the federal courts. Nor did they state in the Supremacy Clause that the law of nations had the status of supreme federal law.

The significance of these omissions is heightened by the fact that some of the proposed drafts of the Constitution would have included

(codified at 28 U.S.C. $§ 1350$ note (1992)).

43. Id. $\S \S 2(\mathrm{~b})-3$.

44. For discussion of the implications of the Torture Victim Protection Act for international human rights litigation, see Bradley \& Goldsmith, supra note 21, at 363-68.

45. See 18 U.S.C. $\S \S 2331-38$ (authorizing damages actions by U.S. nationals for international terrorism, defining international terrorism and other terms, providing for jurisdiction and venue, specifying statute of limitations, and identifying other limitations); 28 U.S.C. $§ 1605$ note (authorizing damages actions against state sponsors of terrorism and specifying relief that can be recovered, the potential defendants, the statute of limitations, and limits on discovery).

46. U.S. CONST. art. I, § 8, cl. 10. 
cases arising under the law of nations within the federal courts' jurisdiction. ${ }^{47}$ The Pinckney Plan would have given the Supreme Court appellate jurisdiction over state court decisions "in all Causes wherein Questions shall arise ... on the Law of Nations." ${ }^{\text {"48 }}$ Similarly, although the record is not entirely clear, there is evidence suggesting that the New Jersey Plan would have given the federal judiciary the authority to hear, on appeal, all cases "which may arise ... on the Law of Nations, or general commercial or marine Laws." ${ }^{, 49}$ But that proposed language was never adopted. Instead, the draft that emerged from the Convention's Committee of Detail listed specific cases and controversies, some of which, like admiralty cases and controversies involving ambassadors, would be likely to involve the law of nations. ${ }^{50}$ The Founders' delineation of these specific cases and controversies, combined with their decision not to adopt proposed language mentioning the law of nations, suggests that they were not implicitly granting a general law of nations jurisdiction in the "Laws of the United States" language in Article III.

There are a number of possible reasons why the Founders would have decided not to grant the federal courts a general law of nations jurisdiction. First, they might have believed that a grant of jurisdiction over all cases arising under the law of nations would be too vague. This possibility is suggested by a debate that occurred late in the Convention concerning Congress's power with respect to the law of nations. The

47. There was a proposal along these lines even before the Federal Convention. In 1786, it was proposed that the Articles of Confederation be amended to create a federal judicial court with the power to review "all Causes wherein questions Shall arise on the meaning and construction of Treaties entered into by the United States with any foreign power, or on the Law of Nations." 1 THE DOCUMENTARY HISTORY OF THE RATIFICATION OF THE CONSTITUTION 167 (Merrill Jensen ed., 1976). After arriving at the Federal Convention in late May 1787, George Mason stated in a letter that the "most prevalent idea" at the Federal Convention was "a total change of the federal system," which included "establish[ing] . . a judiciary system with cognizance of all such matters as depend upon the law of nations, and such other objects as the local courts of justice may be inadequate to." Letter from George Mason to Arthur Lee (May 21, 1787), in 3 THE RECORDS OF THE FEDERAL CONVENTION OF 1787, at 24 (Max Farrand ed., 1911). It is not clear what weight should be accorded to Mason's statement, however, given his own acknowledgement in the letter that he had just arrived in Philadelphia the night before and had "found so few of the deputies here from the several States that I am unable to form any certain opinion on the subject of our mission." Id.

48. 2 THE RECORDS OF THE FEDERAL CONVENTION OF 1787, at 136 (Max Farrand ed., 1911); 3 THE RECORDS OF THE FEDERAL CONVENTION, supra note 47, at 117, 608.

49. 2 THE RECORDS OF THE FEDERAL CONVENTION, supra note 48, at 157. Max Farrand states that the portion of the document containing this phrase, which is in James Wilson's handwriting, is "evidently from the New Jersey plan." Id. at 157 n.15. But cf. 1 THE RECORDS OF THE FEDERAL CONVENTION OF 1787, at 244 (Max Farrand ed., 1911) (Madison's description of the New Jersey plan, which does not contain a reference to the law of nations).

50. See 2 THE RECORDS OF THE FEDERAL CONVENTION, supra note 48, at 186. 
draft of the Constitution being considered at that point would have given Congress the power to define and punish piracies and felonies on the high seas, but only the power to punish offenses against the law of nations. Gouveneur Morris proposed an amendment giving Congress the power to define as well as punish such offenses. ${ }^{51}$ James Wilson objected to that proposal, on the ground that " $[t]$ o pretend to define the law of nations which depended on the authority of all the Civilized Nations of the World, would have a look of arrogance that would make us look ridiculous. ${ }^{~} 52$ In response, Morris argued that adding the word "define" was proper because the law of nations is "often too vague and deficient to be a rule." 53 In apparent agreement, the Convention proceeded to approve Morris's motion. The Founders may similarly have concluded that the law of nations was too vague to serve as a jurisdictional category in Article III.

Second, the Founders may not have wanted to give the federal courts jurisdiction over certain law of nations issues. At the time of the constitutional Founding, the "law of nations" was not limited to the rights and duties of nations. It also included admiralty law, the law governing conflict of laws, and, importantly for present purposes, general commercial law. ${ }^{54}$ Indeed, the "law merchant" applied in the famous Swift v. Tyson decision was often treated in the eighteenth and nineteenth centuries as a component of the law of nations. As Blackstone had explained in his Commentaries, "the affairs of commerce are regulated by a law of their own, called the law merchant or lex mercatoria, which all nations agree in and take notice of." 55 This law merchant, as Blackstone further explained, was "a branch of the law of nations. ${ }^{.56}$ As a result, if Article III allowed the federal courts to hear

51. See id. at 614.

52. Id. at 615 .

53. Id.; see also THOMAS SERGEANT, CONSTITUTIONAL LAW: BEING A VIEW OF THE PRACTICE AND JURISDICTION OF THE COURTS OF THE UNITED STATES, AND OF CONSTITUTIONAL POINTS DECIDED 333 (2d ed. 1830) ("Offences against the law of nations cannot, with any accuracy, be said to be completely ascertained and defined in any public code, recognised by the common consent of nations. In respect to these, there is a peculiar fitness in giving [Congress] the power to define, as well as to punish."); United States v. Smith, 18 U.S. (5 Wheat.) 153,159 (1820) (similar statement).

54. See Clark, supra note 34, at 1279-83; Edwin D. Dickinson, The Law of Nations as Part of the National Law of the United States, 101 U. PA. L. REV. 26, $27-29$ (1952); Jay, supra note 34, at 821-22; see also Max Rheinstein, The Constitutional Bases of Jurisdiction, 22 U. CHI. L. REV. 775, 802-12 (1955) (conflict of laws).

55. 1 WilLIAM BLACKSTONE, COMMENTARIES ON THE LAWS OF ENGLAND 264 (1765).

56. 4 WILLIAM BLACKSTONE, COMMENTARIES ON THE LAWS OF ENGLAND 67 (1769); see also 1 THE WORKS OF THE HONOURABLE JAMES WILSON 374-75 (Bird Wilson ed., 1804) (describing the law merchant as a branch of the law of nations); Swift v. Tyson, 41 U.S. (16 Pet.) 1, 37-38 (1842) ("The law respecting negotiable instruments may be truly declared ... to be in a 
all cases arising under the law of nations, it would mean that they potentially could hear all cases involving general commercial law, even in disputes between citizens of the same state. Yet, as Professor Stewart Jay has noted, "[i]t would have been highly controversial for the Framers to recommend that ordinary contract cases involving citizens of the same state be sent to federal courts. $\$ 57$

Finally, it is possible that the Founders believed that their specific list of cases and controversies would encompass all of the disputes likely to implicate the United States' international relations. ${ }^{58}$ The records of the Convention's Committee of Detail suggest that it was attempting to delineate the categories of jurisdiction that would involve "the national peace and harmony." 59 Considered as a whole, the categories that it delineated gave the federal courts substantial authority to hear disputes involving the law of nations. Some cases involving the law of nations would implicate treaties, and Article III grants the federal courts the authority to hear "all Cases ... arising under ... Treaties." ${ }^{.60}$ In addition, many law of nations disputes at that time would involve admiralty matters, and Article III authorized the federal courts to hear "all Cases of admiralty and maritime Jurisdiction." ${ }^{.61}$ As discussed below in Part IV, cases involving ambassadors also would likely implicate the law of nations, and Article III grants the Supreme Court the authority to hear "all Cases affecting Ambassadors, other public Ministers and Consuls." ${ }^{12}$ Furthermore, the Constitution gives Congress the power to define and punish offenses against the law of nations, and any cases arising under such congressional enactments would fall within Article III's allowance of jurisdiction over "Cases ... arising under ... the Laws of the United States."

Whatever the reason, the constitutional text could have, but does not,

great measure, not the law of a single country only, but of the commercial world."); Michael Conant, The Commerce Clause, the Supremacy Clause, and the Law Merchant: Swift v. Tyson and the Unity of Commercial Law, 15 J. MAR. L. \& COM. 153, 153-54 (1984) (noting that Swift involved an "application of . . . international law").

57. Jay, supra note 34 , at 832 .

58. See id. at 831 .

59. See 2 THE RECORDS OF THE FEDERAL CONVENTION, supra note 48 , at $132-33,146-47$ (drafts considered by Committee of Detail).

60. U.S. CoNST. art. III, $\S 2$, cl. 1.

61. Id. In The Federalist, Alexander Hamilton noted that the proposed grant of admiralty jurisdiction was uncontroversial, and that many of the cases falling within this jurisdiction would implicate the law of nations: "The most bigoted idolizers of State authority have not thus far shown a disposition to deny the national judiciary the cognizance of maritime causes. These so generally depend on the laws of nations and so commonly affect the rights of foreigners, that they fall within the considerations which are relative to the public peace." THE FEDERALIST NO. 80, supra note 25 , at 478 .

62. U.S. CONST. art. III, $\S 2$, cl. 2. 
grant the federal courts general "arising under" jurisdiction over cases involving the law of nations. There is, to be sure, a potentially contrary suggestion by John Jay in one of the Federalist Papers. In Federalist No. 3, Jay states as follows:

Under the national government, treaties and articles of treaties, as well as of the laws of nations, will be always expounded in one sense and executed in the same manner-whereas adjudications on the same points and questions in thirteen States, or in three or four confederacies, will not always accord or be consistent.... The wisdom of the convention in committing such questions to the jurisdiction of courts appointed by and responsible only to one national government cannot be too much commended. ${ }^{63}$

One could read this statement as suggesting that, under the proposed Constitution, the federal courts would have the power to hear all cases arising under the law of nations, just as they would have the power to hear all cases arising under treaties. Jay's essay, however, does not contain a description or defense of Article III's specific language, and it certainly does not mention the "Laws of the United States" language. The purpose of this early Federalist Paper, rather, was simply to defend the general scheme of the proposed Constitution. With this in mind, one could read Jay as merely stating, as a general proposition, that the Constitution would allow the federal courts broad authority to hear "such questions" of international law. This was of course true, since the Constitution authorized the federal courts to hear all cases arising under treaties, and it included within their jurisdiction a variety of cases and controversies that would likely implicate the law of nations.

In any event, more direct evidence of the intended scope of Article III comes from the Federalist essays that, unlike Federalist No. 3, specifically discuss the proposed jurisdiction of the federal courts. Most notable in this regard is Federalist No. 80, authored by Alexander Hamilton, which carefully delineates and defends Article III's list of cases and controversies. Despite being a vigorous proponent of a strong national government, it is clear from Federalist No. 80 that Hamilton did not view the "Laws of the United States" in Article III as including the law of nations. In that essay, Hamilton outlines six categories of cases that should be heard in the federal courts. Hamilton then proceeds to link those categories to the specific jurisdictional provisions in Article III. In doing so, he links the allowance of jurisdiction over cases "arising under the Constitution and the laws of the United States" only to his first two categories; which involve cases "which arise out of the

63. THE FEDERALIST NO. 3, supra note 25, at 41, 43 (John Jay). 
laws of the United States, passed in pursuance of their just and constitutional powers of legislation" and cases "which concern the execution of the provisions expressly contained in the articles of Union. ${ }^{.64}$ As is clear from the italicized language, Hamilton understood the phrase "Laws of the United States" in Article III as referring to federal statutory law, and therefore as not encompassing unwritten law, such as the law of nations. This conclusion is confirmed by the fact that Hamilton proceeds to link his fourth category-which covered those cases "which involve the PEACE of the CONFEDERACY," including cases implicating the law of nations-only to Article III's party-based grants of jurisdiction and to the reference in Article III to cases arising under treaties, not to the grant of jurisdiction in Article III over cases arising under the "Laws of the United States."

Historical evidence suggests that, in enacting the First Judiciary Act, Congress similarly did not think that the "Laws of the United States" in Article III encompassed the law of nations. ${ }^{66}$ As an initial matter, it

64. THE FEDERALIST No. 80, supra note 25, at 475, 475-77 (Alexander Hamilton) (emphasis added to second quote).

65. See id. at 447-49; see also Weisburd, supra note 19, at 1222 \& 1221 n.79 (making similar observations about Federalist No. 80). Several years later, writing as "Pacificus," Hamilton expressed the view that the law of nations was included within the "Laws" referred to in Article II, Section 3, which states that the President "shall take Care that the Laws be faithfully executed." See Alexander Hamilton, Letters of Pacificus, No. l (June 29, 1793), in 15 THE PAPERS OF AleXANDER HAMILTON 33, 34, 41, 43 (Harold C. Syrett ed., 1969). This Take Care Clause refers generically to "Laws," not "Laws of the United States," and Hamilton did not suggest that he was retreating from the construction of "Laws of the United States" that he had articulated in The Federalist. In addition, Hamilton distinguished in "Pacificus" between the law of nations and "municipal law," see $i d$. at 40, further suggesting that he did not view the law of nations as part of the "Laws of the United States." In any event, there is evidence that, contrary to Hamilton's statement in "Pacificus," the Founders did not intend the word "Laws" in Article II to refer to the law of nations. All of the proposed drafts of the Take Care Clause, including the draft that emerged from the Committee of Detail, limited it to U.S. laws, and at least some of these drafts appear to have been referring specifically to federal legislation. See 1 THE RECORDS OF THE FEDERAL CONVENTION, supra note 49, at 21 (Virginia Plan) ("the National laws"); id. at 64, 67 (Committee of the Whole) ("the national laws"); id. at 244 (New Jersey Plan) ("the federal acts"); id. at 292 (Hamilton Plan) ("all laws passed"); 2 THE RECORDS OF THE FEDERAL CONVENTION, supra note 48, at 158 (Pinckney Plan) ("Laws of the U.S."); id. at 185 (Committee of Detail) ("laws of the United States"). The deletion of this qualifying language at the end of the Convention by the Committee of Style, apparently without debate, see id. at 600 , was probably intended to make clear that the Take Care Clause encompassed not only federal legislation, but also the other two forms of supreme federal law-the Constitution and treaties. See, e.g., William RAWLE, A VIEW OF THE CONSTITUTION OF THE UNITED STATES OF AMERICA 136 (1825) (construing the Take Care Clause as referring to "[t]he constitution, treaties, and acts of congress").

66. For general discussion of the drafting history of the First Judiciary Act, see JULIUS GOEBEL JR., 1 HISTORY OF THE SUPREME COURT OF THE UNITED STATES: ANTECEDENTS AND BEGINNINGS TO 1801, at ch. XI (1971); WILFRED J. RITZ, REWRITING THE HISTORY OF THE JUDICIARY ACT OF 1789 (1990); Charles Warren, New Light on the History of the Federal Judiciary Act of 1789, 37 HARV. L. REV. 49 (1923). 
seems almost certain that Congress did not believe that the law of nations was part of the "Laws of the United States" referred to in a different part of the Constitution-the Supremacy Clause of Article VI. That Clause refers to laws "made in Pursuance" of the Constitution, yet the law of nations was not understood as being made in pursuance of the U.S. Constitution. Instead, it was understood as stemming from either natural law or the customs of the international community, and judges involved in applying this law were seen as involved in a process of discovery rather than creation. ${ }^{67}$ As Blackstone explained, the law of nations was "a system of rules, deducible by natural reason, and established by universal consent among the civilized inhabitants of the world." James Wilson similarly explained in his 1790-91 Lectures on Law that the law of nations was "of origin divine" and was "the law of nature applied to states and sovereigns." ${ }^{69}$ In light of this understanding of the law of nations, it is highly unlikely that the Founders or the First Congress would have thought of the law of nations as made in pursuance of the U.S. Constitution.

This conclusion is confirmed by the language of Section 34 of the Judiciary Act-the so-called "Rules of Decision Act." In that section, Congress directed the federal courts to apply "the laws of the several states" as the rules of decision "in cases where they apply," "except where the constitution, treaties, or statutes of the United States shall otherwise require or provide." ${ }^{370}$ Thus, pursuant to this provision, federal

67. See Jay, supra note 34 , at $822-24,832-33$.

68. 4 BLACKSTONE, supra note 56 , at 66 .

69. 1 THE WORKS OF JAMES WILSON, supra note 56, at 147, 150; see also Draft of John Jay's Charge to the Grand Jury of the Circuit Court for the District of Virginia (before Apr. 22, 1793), in 2 THE DOCUMENTARY HISTORY OF THE SUPREME COURT OF THE UNITED STATES, 1789-1800, at 359, 361 (Maeva Marcus ed., 1988) ("It may be asked who made the Laws of Nations. The answer is he from whose will proceed all moral Obligations, and which will is made known to us by Reason or by Revelation.").

70. Although not directly relevant to this issue, the Supreme Court in Swift v. Tyson famously interpreted the phrase "laws of the several states" in Section 34 as referring only to state statutes and state judicial decisions relating to "local" matters, not state judicial decisions relating to the general common law. 41 U.S. (16 Pet.) 1, 18-19 (1842). As originally drafted (apparently by Ellsworth), Section 34 referred to "the Statute law of the several States in force for the time being, \& their unwritten or common law now in use, whether by adoption from the common law of England, the ancient Statutes of the same or otherwise." 4 THE DOCUMENTARY HISTORY OF THE SUPREME COURT OF THE UNITED STATES, 1789-1800, at 105-06 (Maeva Marcus ed., 1992). Charles Warren, in an article cited by the Supreme Court in Erie v. Tompkins, 304 U.S. 64 (1938), argued that this draft language showed that the First Congress intended for the federal courts to apply state common law in diversity cases. Warren, supra note 66, at 86-88. But cf. Henry J. Friendly, In Praise of Erie-And of the New Federal Common Law, 39 N.Y.U. L. REV. 383, 390 (1964) (noting that the deletion of this language by the First Congress could cut either way).

Professor Collins suggests that federal courts interpreted the phrase "in cases where they apply" in the Rules of Decision Act as allowing them to apply general common law, including the law of nations, even when it conflicted with a state statute. Collins, supra note 21 , at 663 . 
courts were to apply state law even when it conflicted with the unwritten law of nations, a strange result if the law of nations was considered supreme federal law. Indeed, if the First Congress believed that the law of nations was part of supreme federal law, it would mean that they thought that state courts should apply the law of nations in place of any conflicting state law (as they would be required to do under the Supremacy Clause), but that federal courts should do the exact opposite and apply state law over any conflicting law of nations. It is hard to imagine that the First Congress would have intended such a regime. ${ }^{71}$ In any event, the key point is that Section 34 shows that the First Congress thought of supreme federal law as consisting of the Constitution, treaties, and federal statutes, not the unwritten law of nations.

It is possible, of course, that "Laws of the United States" in Article III is broader than "Laws of the United States . . . made in Pursuance [of the Constitution]" in Article VI. Indeed, William Crosskey made this argument in his famous (and highly controversial) treatise, Politics and the Constitution. ${ }^{72}$ Crosskey's analysis, however, is less than convincing.

Crosskey made two arguments. ${ }^{73}$. First, Crosskey emphasized the

Professor Collins relies on an article by Professor (now Judge) Fletcher for this proposition, but Fletcher actually noted in that article that "[t]he Supreme Court followed established state court interpretations of state statutes fairly consistently," and that "it was beyond question that a state had substantial power to establish a rule different from that of the general common law." Fletcher, supra note 35, at 1533, 1538; see also Clark, supra note 34, 1286-87 \& n.192 (making similar point, and noting that this was made clear in Swift v. Tyson); Stewart Jay, Origins of Federal Common Law: Part Two, 133 U. PA. L. REV. 1231, 1265-66 (1985) (noting that "federal courts [were] obligated to follow state statutes regarding general law matters and 'settled' constructions given the statutes").

71. In an early and important Supreme Court decision confirming the supremacy of treaties over state law, two justices specifically stated that the law of nations did not preempt inconsistent state law, and the other justices did not assert the contrary. Ware v. Hylton, 3 U.S. (3 Dall.) 199, 229 (1796) (Chase, J.); id. at 265-66 (Iredell, J.); see also DAVID P. CURRIE, THE CONSTITUTION IN THE SUPREME COURT: THE FIRST HUNDRED YEARS, 1789-1888, at 37-38 (1985) (noting this point).

72. 1 William Winslow CROSSKEy, POLITICS AND THE CONSTITUTION IN THE History OF THE UNITED STATES 620-22 (1953). For criticism of this treatise, see, for example, Julius Goebel, Jr., Ex Parte Clio, 54 ColuM. L. REV. 450 (1954); Henry M. Hart, Jr., Professor Crosskey and Judicial Review, 67 HARV. L. REV. 1456 (1954); and Ernest J. Brown, Book Review, 67 HARV. L. REV. 1439 (1954). See also PhILIP BOBBITT, Constitutional Fate: THEORY OF THE CONSTITUTION 15-24 (1982) (describing some of the criticism of Crosskey's treatise).

73. Professor Dodge makes the same arguments in his comment on this Article. See Dodge, supra note 27, at 703-07; see also Michael D. Ramsey, International Law as Part of Our Law: A Constitutional Perspective, 29 PEPPERDINE L. REV. (forthcoming 2002) (suggesting that there might be a difference between the "Laws of the United States" referred to in Article III and the "Laws of the United States ... made in Pursuance [of the Constitution]" referred to in Article 
"made in Pursuance" language that appears in Article VI but not in Article III. This difference in wording, argued Crosskey, showed that the "Laws of the United States" referred to in Article III was broader than the "Laws of the United States" referred to in Article VI. There is no evidence from the Founding materials, however, suggesting that the "made in Pursuance" language was intended to limit the class of "Laws of the United States." It is just as likely that this "made in Pursuance" language was intended as a confirmation of the Constitution's supremacy over federal statutes, something that the Founders would have had more reason to emphasize in the Supremacy Clause than in the jurisdictional provisions of Article III. This is what Alexander Hamilton appears to have had in mind in Federalist No. 33, when he describes the "made in Pursuance" language "as an instance of caution in the convention; since that limitation would have been understood, though it had not been expressed."'74

Second, Crosskey relied on the fact that the draft of Article III that emerged from the Committee of Detail referred to "Laws passed by the Legislature of the United States," but the "passed by the Legislature" language was deleted on a motion by John Rutledge. ${ }^{75}$ The deletion of this language, Crosskey argued, shows that the Founders intended to encompass non-statutory law within the phrase "Laws of the United States." Unfortunately for Crosskey's argument, the Committee of Detail's draft of the Supremacy Clause contained a similar reference to the legislature, and that reference had just been deleted a few days earlier on a motion by Rutledge, even though, as Crosskey acknowledges, the Founders did not intend the Supremacy Clause to encompass unwritten law. ${ }^{76}$ Neither the records of the Federal Convention nor the subsequent state ratification debates indicate why the references to the legislature were deleted from these provisions, and this silence alone may suggest that the deletions were not intended to have substantive effect. The deletions were made at the same time that references to the Constitution were added to Articles III and VI (and a reference to treaties was added to Article III), ${ }^{77}$ and it seems quite possible that the Convention delegates simply intended to condense the reference to federal statutes and make it fit better in what was now a list

VI).

74. THE FEDERALIST No. 33, supra note 25, at 201, 205 (Alexander Hamilton).

75. Compare 2 THE RECORDS OF THE FEDERAL CONVENTION, supra note 48 , at 186 , with id. at 431 .

76. Compare id. at 183 (referring to "[t]he Acts of the Legislature of the United States"), with id. at 389 (eliminating that language based on a motion by Rutledge). This fact also undermines Professor Dodge's similar argument. See Dodge, supra note 27, at 707.

77. See id. at $389,430,431$. 
of three types of laws. ${ }^{78}$ In any event, the key point is that the deletions do not by themselves suggest a reason to distinguish between "Laws of the United States" in Article III and "Laws of the United States" in Article VI.

In sum, neither of Crosskey's arguments provides a strong reason for interpreting the class of "Laws of the United States" differently in Articles III and VI. There are, however, numerous statements in the Founding materials suggesting that the phrase "Laws of the United States" in Article III refers only to federal statutes. As noted above, this was Hamilton's understanding in Federalist No. 80. Similarly, in describing the proposed jurisdiction of the federal courts during the Virginia ratification debates, Edmund Pendleton referred to their jurisdiction over cases arising under the laws of the United States as jurisdiction over cases arising "under the laws of the Federal Legislature." ${ }^{, 79}$ And, in responding to an argument that the federal courts might act unconstitutionally in exercising their jurisdiction over cases arising under the "Laws of the United States;" James Wilson stated in the Pennsylvania convention that, "If a law should be made inconsistent with those powers vested by this instrument in Congress, the judges ... will declare such law to be null and void." ${ }^{180}$ Furthermore, writing as "Landholder," Oliver Ellsworth, who later played a lead role in drafting the First Judiciary Act, argued that the federal courts would not interfere with the internal policy of the states because they would "have cognizance only of those subjects which are placed under the control of a national legislature."

78. In adding a reference to treaties in Article III, the Convention delegates self-consciously duplicated an amendment they had made two days earlier to the Supremacy Clause's treaty provision, further suggesting that they were trying to have the three types of laws in Article III match the three types of laws in the Supremacy Clause. See id. at 417 (amendment to treaty provision in Supremacy Clause); id. at 431 (using same language for treaty provision in Article III "conformably to a preceding amendment in another place").

79. 10 THE DOCUMENTARY HISTORY OF THE RATIFICATION OF THE CONSTITUTION 1398 (John P. Kaminski \& Gaspare J. Saladino eds., 1993); see also id. at 1413 (James Madison) (stating, in reference to the proposed jurisdiction of the federal courts over cases arising under the laws of the United States, that "it is so necessary and expedient that the Judicial power should correspond with the Legislative, that it has not been objected to").

80. 2 THE DOCUMENTARY History OF THE RATIFICATION OF THE CONSTITUTION 517 (Merrill Jensen ed., 1976) (emphasis added).

81. 3 THE DOCUMENTARY HistoRY OF THE RATIFICATION OF THE CONSTITUTION 483 (Merrill Jensen ed., 1978) (emphasis added). For similar statements in the North Carolina ratification debates, see 4 ThE DeBates IN THE SEVERAL STATE CONVENTIONS ON THE ADOPTION OF THE FEDERAL CONSTITUTION 139 (Jonathan Elliot ed., 1974) (Spaight); id. at 146 (Iredell); id. at 158 (Davie). Professor Dodge suggests that a statement by William Grayson during the Virginia debates shows a belief that the "Laws' of the United States" in Article III included the law of nations. Dodge, supra note 27, at 708-09. Grayson, however, merely observed that the Supreme Court could hear cases "depending on the law of nations"; he made no claim 
assumption that "Laws of the United States" meant laws made by Congress.

Similar statements can be found in the legislative record of the First Judiciary Act. ${ }^{82}$ At one point in the deliberations, Senator William Maclay objected to a motion to restrict the jurisdiction of the federal courts to admiralty cases, noting that Article III extended federal court jurisdiction "to all cases in law and equity under the Constitution[,] the Laws of the united States, [and] Treaties made or to be made," and that "we already had existing Treaties and were about making many laws." Maclay appears to have understood that "Laws of the United States" in Article III referred to laws made by Congress. Similarly, Representative Fisher Ames argued against a proposal to vest the proposed federal court jurisdiction with the state courts, because "State judges are to judge according to the law of the State, and the common law," which Ames distinguished from "[t]he law of the United States." ${ }^{\text {" }}$ Ames thus distinguished the "Laws of the United States" in Article III from the "common law." In answer to Ames's argument, Representative James Jackson noted that the Supremacy Clause makes the laws of the United States supreme over state law, thus ensuring that state courts would in fact apply these laws. ${ }^{85}$ Jackson's equation of the "Laws of the United States" reference in Article III with the "Laws of the United States" reference in Article VI is further confirmation that they were thinking of federal statutes. ${ }^{86}$

that this authority stemmed from the reference in Article III to "Laws of the United States." See 10 THE DOCUMENTARY HISTORY OF THE RATIFICATION, supra note 79, at 1445-46. As discussed above, many of the other categories of jurisdiction authorized by Article III encompassed cases "depending on the law of nations." In fact, Grayson himself immediately proceeded to discuss (and complain about) alienage jurisdiction. Id. at 1447.

82. The record consists primarily of the drafts of the Judiciary Act, the recorded House debates, the descriptions of the Senate debates in Senator William Maclay's diary, and correspondence to and from members of Congress. A good source for the correspondence is 4 THE DOCUMENTARY HISTORY OF THE SUPREME COURT, supra note 70, which was published in 1992 and thus was not available when some of the prior articles on the Alien Tort Statute were written.

83. 9 DOCUMENTARY HISTORY OF THE FIRST FEDERAL CONGRESS 85 (Kenneth R. Bowling \& Helen E. Veit eds., 1988) (Diary of William Maclay).

84. 11 DOCUMENTARY HISTORY OF THE FIRST FEDERAL CONGRESS, supra note 24, at 1358 (remarks of Fisher Ames on Aug. 29, 1789).

85. Id, at 1360. For similar responses from Representatives Michael Stone and Samuel Livermore, see $i d$. at 1382, 1389-90.

86. For a detailed explanation of why the text of Section 25 of the Judiciary Act, which regulated Supreme Court review of state court decisions, also shows that the First Congress equated the "Laws of the United States" in Article III with federal statutes, see John C. Harrison, The Judiciary Act of 1789 and Unwritten Law as Law of the United States (unpublished draft, on file with author). When the Supreme Court eventually construed the phrase "laws of the United States" in Section 2S, it repeatedly held, consistent with Harrison's argument, that the phrase did not encompass the law of nations. See, e.g., Ker v. Illinois, 119 U.S. 436, 444 (1886) (holding that 
Early commentaries on American law further support this conclusion. In his version of Blackstone's Commentaries, published in 1803, St. George Tucker appears to assume that the "Laws of the United States" in Article III refers to federal statutes, and, on that basis, argues that jurisdiction under this clause will be "limited to the same subjects as congress have power to legislate upon." treatise on federal court jurisdiction published in 1824, states even more directly that, in adopting the "Laws of the United States" reference in Article III, it appears that "the framers of the Constitution only meant the statutes which should be enacted by the national Legislature." ${ }^{188}$ Joseph Story similarly states in his 1833 constitutional law treatise that "cases arising under the laws of the United States, are such as grow out of the legislation of Congress." "89

This conclusion-that the "Laws of the United States" in Article III was not viewed as encompassing unwritten law, including the law of nations-is not undermined by the allowance of common law prosecutions in the federal courts in the late 1700 s. In the preconstitutional period, some state courts had allowed prosecutions based on the law of nations, reasoning that the law of nations was incorporated into their state common law. ${ }^{90}$ Similarly, before the Supreme Court disallowed the practice in $1812,{ }^{91}$ some federal courts allowed prosecutions based on the law of nations, as well as other unwritten law. ${ }^{92}$ There is significant scholarly disagreement over the extent to

a state court's ability to criminally prosecute a person who has been forcibly abducted from another country does not implicate "the Constitution, or laws, or treaties, of the United States," but rather is "a question of common law, or of the law of nations .... which we have no right to review"); City \& County of San Francisco v. Scott, 111 U.S. 768, 769 (1884) (holding that the effect of the United States' conquest of California on property rights in San Francisco "[did] not depend on any legislation of Congress, or on the terms of the treaty," but rather was "a question of general public law, as to which the decisions of the State Court are not reviewable here"); New York Life Ins. Co. v. Hendren, 92 U.S. 286, 286-87 (1875) (holding that the Supreme Court has no jurisdiction to review "general laws of war, as recognized by the law of nations applicable to this case," because they do not involve "the constitution, laws, treaties, or executive proclamations, of the United States"); see also A.M. Weisburd, State Courts, Federal Courts, and International Cases, 20 YALE J. INT'L L: 1, 38-40 (1995) (discussing these and other decisions).

87. 1 ST. GEORGE TUCKER, supra note 28, at app. 419.

88. PETER S. DUPONCEAU, A Dissertation ON THE NATURE AND EXTENT OF THE JURISDICTION OF THE COURTS OF THE UNITED STATES 99 (1824).

89. 3 JOSEPH STORY, COMMENTARIES ON THE CONSTITUTION OF THE UNITED STATES § 1641, at 508 (1833); see also 1 JAMES KENT, COMMENTARIES ON AMERICAN LAW 320 (1826) ("[T]he judiciary power of the United States cannot take cognizance of offences at common law, unless they have jurisdiction over the person or subject matter, given them by the constitution or laws made in pursuance of it.").

90. See, e.g., Respublica v. De Longchamps; 1 U.S. (1 Dall.) 111 (1784).

91. See United States v. Hudson \& Goodwin, 11 U.S. (7 Cranch) 32 (1812); United States v. Coolidge, 14 U.S. (1 Wheat.) 415 (1816).

92. See generally WiLliam R. CASTO, THE SuPREME COURT IN THE EARLY REPUBLiC: ThE 
which the federal court practice was consistent with the Founders' and First Congress's intent. ${ }^{93}$ The key point for present purposes, however, is that these federal criminal prosecutions did not depend on the proposition that the law of nations (or any unwritten law) was part of the "Laws of the United States" in Article III. This is because the First Judiciary Act did not specifically tie the criminal jurisdiction of the federal courts to the "Laws of the United States" category of Article III jurisdiction or to any other particular category of jurisdiction. Rather, it merely required that the offense be "cognizable under the authority of the United States." 94 The Act thus allowed for federal court jurisdiction over criminal cases as long as the case fell within any of the Article III categories. ${ }^{95}$

There were only a handful of common law prosecutions in the federal courts, and only a few of them involved the law of nations. ${ }^{96}$ Most notable were Henfield's Case and Williams Case, both of which involved privateering by U.S. citizens on behalf of France, in violation

CHIEF JUSTICESHIPS OF JOHN JAY AND OLIVER ELLSWORTH 129-47 (1995).

93. See generally Stewart Jay, Origins of Federal Common Law: Part One, 133 U. PA. L. REV. 1003 (1985); Stewart Jay, Origins of Federal Common Law: Part Two, 133 U. PA. L. REV. 1231 (1985); Robert C. Palmer, The Federal Common Law of Crime, 4 LAW \& HIST. REV. 267 (1986); Stephen B. Presser, A Tale of Two Judges: Richard Peters, Samuel Chase, and the Broken Promise of Federalist Jurisprudence, 73 NW. U. L. REV. 26 (1978); Stephen B. Presser, The Supra-Constitution, the Courts, and the Federal Common Law of Crimes: Some Comments on Palmer and Preyer, 4 LAW \& HIST. REV. 325 (1986); Kathryn Preyer, Jurisdiction to Punish: Federal Authority, Federalism and the Common Law of Crimes in the Early Republic, 4 LAW \& HIST. REV. 223 (1986); Gary D. Rowe, Note, The Sound of Silence: United States v. Hudson \& Goodwin, the Jeffersonian Ascendancy, and the Abolition of Federal Common Law Crimes, 101 YALE L.J. 919 (1992).

94. Section 9 gave the district courts jurisdiction over such offenses "where no other punishment than whipping, not exceeding thirty stripes, a fine not exceeding one hundred dollars, or a term of imprisonment not exceeding six months, is to be inflicted." Section 11 gave the circuit courts exclusive jurisdiction over more serious offenses and concurrent jurisdiction over the offenses that could be heard in the district courts. The original committee draft of these provisions referred to offenses "cognizable under the authority of the United States and defined by the laws of the same" and offenses "cognizable under the authority of the United States and defined by the laws of the land," but the phrases "and defined by the laws of the same" and "and defined by the laws of the land" were deleted by the full Senate. Some scholars have argued that this deletion shows that the First Congress intended to allow for common law prosecutions in the federal courts, including prosecutions under the law of nations. See, e.g., Warren, supra note 66, at 73-74, 77. But cf. GOEBEL, supra note 66, at 496 (suggesting that the words may have been deleted merely because they were redundant).

95. See United States v. Coolidge, 25 F. Cas. 619, 619-20 (1813) ("The jurisdiction [of the federal courts in criminal cases] is not, as has sometimes been supposed in argument, over all crimes and offences specially created and defined by statute. It is of all crimes and offences 'cognizable under the authority of the United States,' that is, of all crimes. and offences, to which by the constitution of the United States, the judicial power extends."), rev'd on other grounds, 14 U.S. 415 (1816).

96. Preyer, supra note 93, at 229-30. 
of the U.S. policy of neutrality. In both of these cases, bases for jurisdiction existed other than the "Laws of the United States" provision in Article III-in particular, jurisdiction existed because the cases involved treaties and admiralty matters. Thus, the fact that the judges in these cases believed that offenses against the law of nations were "cognizable under the authority of the United States" does not show that these judges viewed the law of nations as part of the "Laws of the United States" in Article III. ${ }^{97}$ Rather, as William Rawle, one of the prosecutors in Henfield's Case, had argued, the law of nations provided a common law rule of decision. As he explained, "The law of nations is part of the law of the land.... This is an offence against the laws of nations. It is punishable by indictment on information as such."98 In support of this claim, Rawle cited Blackstone's Commentaries and a Pennsylvania decision holding that the law of nations was part of the state's common law. ${ }^{99}$

John Marshall emphasized this point-that the common law was used in these cases as a rule of decision, not as a basis for jurisdiction-in a letter to Henry St. George Tucker in $1800{ }^{100}$ Tucker had sent Marshall a pamphlet entitled Examination of the Question "How Far the Common Law of England is the Law of the Federal Government of the United States?," which Tucker later reprinted as an appendix to his version of Blackstone's Commentaries. ${ }^{101}$ In the pamphlet, Tucker had argued that the Constitution had not incorporated the common law as federal law. ${ }^{102}$

97. To the extent that the Article III issue was addressed outside the context of admiralty and treaty cases, there appears to have been a belief that certain common law offenses arose directly under the U.S. Constitution, not that the common law was part of the "Laws of the United States." William Paterson, who was involved in the drafting the First Judiciary Act, expressed this view regarding the law of nations, after he became a Supreme Court justice. See Casto, supra note 18, at 481 (quoting from a draft opinion by Paterson stating that an offense against the law of nations is "an offence arising under the const[itutio]n, as distinct from an offence arising under the law of the U. States; because we have no stat[ute] on the subject"). The idea that some common law crimes arose under the Constitution appears to have rested on a conception of the phrase "arising under" that is different from the modern conception of that phrase.

98. Henfield's Case, 11 F. Cas. 1099, 1117 (1793) (No. 6,360).

99. Id. In later discussing the case in a letter to James Madison, the other prosecutor, Edmund Randolph, recalled that he had relied on the common law as a state law rule of decision to be applied pursuant to Section 34 of the Judiciary Act and thereby "aid the treaty, which had specified no penalty for Henfield's crime." MONCURE DANIEL CONWAY, OMITTED CHAPTERS OF HISTORY DISCLOSED IN THE LIFE AND PAPERS OF EDMUND RANDOLPH 185 (1888) (quoting the letter).

100. Letter from John Marshall to St. George Tucker (Nov. 27, 1800), in 6 THE PAPERS OF JOHN MARSHALL 23-24 (Charles F. Hobson ed., 1990).

101. See 1 ST. GEORGE TUCKER, supra note 28, at app. 378-433 ("Note E: of the Unwritten, or Common Law of England and Its Introduction Into, and Authority Within the United States"); see also Jay, supra note 70, at app. $1326 \mathrm{n} .1$ (discussing the pamphlet and Tucker's authorship).

102. Tucker may not have been thinking specifically of the law of nations in making this argument, since at one point he distinguishes the common law from the law of nations. See 1 ST. 
Tucker, a Jeffersonian opposed to a federal common law of crimes, apparently anticipated that Marshall, an ardent Federalist, would disagree with his analysis. Marshall replied, however, that he agreed with Tucker and that,

I do not believe one man can be found who maintains the affirmative of this proposition. Neither in public nor in private have I ever heard it advocated, \& I am entirely confident as I can be of any thing of the sort, that it never has been advocated. ${ }^{103}$

Marshall went on to discuss Williams Case. In that case, an individual who had served as an officer on a French warship during its attack on British ships was held to be subject to prosecution in the United States, notwithstanding his attempt to renounce his U.S. citizenship. Oliver Ellsworth, by then the Chief Justice of the United States, instructed the jury that "[t]he common law of this country remains the same as it was before the Revolution," and explained that, under this common law, "members [of this country] cannot dissolve this compact [of citizenship], without the consent or default of the community." 104 In discussing this case in his letter, Marshall emphasized that, "[i]n the case of Williams the common law was not relied on as giving the court jurisdiction, but came in incidentally as part of the law of a case of which the court had complete \& exclusive possession."105 Importantly, Marshall was not backing away from the Federalist position that unwritten law (including the law of nations) could provide a rule of decision in a federal criminal proceeding; he was simply denying that cases arising under this law would arise under the "Laws of the United States" in Article III. As he noted, it was this latter point that "never has been advocated." 106

GEORGE TUCKER, supra note 28, at app. 420. In discussing the phrase "Laws of the United States" in Article III, however, Tucker appears to have believed that it referred only to federal statutes. See id. at app. 419; see also supra text accompanying note 87.

103. Letter from John Marshall to St. George Tucker (Nov. 27, 1800), in 6 THE PAPERS of JOHN MARSHALL, supra note 100 , at 23 .

104. United States v. Williams, 29 F. Cas. 1330, 1331 (C.C.D. Conn. 1799) (No. 17,708).

105. Letter from John Marshall to St. George Tucker (Nov. 27, 1800), in 6 THE PAPERS OF JOHN MARSHALL, supra note 100, at 24. As noted above, Williams Case fell within the Article III admiralty and treaty jurisdiction. Even with respect to the common law offense of sedition, Marshall noted, advocates for federal court prosecution "contended, not that the common law gave the courts jurisdiction ... but that the constitution gave it." Id. at 24; see also Jay, supra note 70, at 1326-33 (reprinting and commenting on Marshall's letter).

106. See also DUPONCEAU, supra note 88, at 19-20 (denying that federal criminal jurisdiction was based on the common law, but arguing that federal courts could "take cognisance of an offence which is only made such by the common law"). In commenting on DuPonceau's discussion of this issue, Fletcher states: "In other words, the common law did not provide jurisdiction to the national courts under the 'arising under' clause of article III, and it could not be derived from the lawmaking powers of the national government." Fletcher, supra note 35, at 
To be sure, certain grand jury charges made by Supreme Court justices riding circuit during this period referred to the law of nations as part of "the law of the United States" or "the law of the land." There is no suggestion in these instructions, however, that the law of nations provided a basis for federal court jurisdiction. Rather, these instructions simply informed the jurors that the law of nations, like other common law, was a proper source of law to be applied in a federal court criminal prosecution. In this respect, the instructions mimicked Blackstone's statement about English law-that "the law of nations (wherever any question arises which is properly the object of it's jurisdiction) is here adopted in it's full extent by the common law, and is held to be a part of the law of the land." 107 Justice Iredell, for example, instructed a grand jury that, "[t]he Common Law of England, from which our own is derived, fully recognizes the principles of the Law of Nations, and applies them in all cases falling under its jurisdiction." 108 Similarly, in Henfield's Case, James Wilson instructed the grand jury that the law of nations was incorporated as part of the common law:

Does a Question arise before her [the common law], which properly ought to be resolved by the Law of Nations? By that Law she will decide the Question: For that Law in its full Extent, is adopted by her. The infractions of that Law form a Part of her Code of criminal Jurisprudence. ${ }^{109}$

Not surprisingly, Wilson cited Blackstone in support of this proposition.

In a number of early decisions, the Supreme Court similarly referred to the law of nations as part of the "common law"10 or the "law of the

1526. Because writers like Marshall and DuPonceau were not retreating from their support for federal common law prosecutions, Professor Dodge is incorrect in dismissing their statements about federal court jurisdiction as simply "the reluctant concessions of vanquished common-law defenders." Dodge, supra note 27 , at 711 .

107. 4 BLACKSTONE, supra note 56 , at 67.

108. James Iredell's Charge to the Grand Jury of the Circuit Court for the District of South Carolina (May 12, 1794), in 2 THE DOCUMENTARY HISTORY OF THE SUPREME COURT, supra note 69, at 467; see also James Iredell's Charge to the Grand Jury of the Circuit Court for the District of Pennsylvania (Apr. 12, 1796), in 3 THE DOCUMENTARY HISTORY OF THE SUPREME COURT OF THE UNITED STATES, 1789-1800, at 111 (Maeva Marcus ed., 1990) (describing a violation of the law of nations as "an offence at common law, in the same manner and upon the same principle as any other offence commited against the common law").

109. James Wilson's Charge to the Grand Jury of a Special Session of the Circuit Court for the District of Pennsylvania (July 22, 1793), in 2 THE DOCUMENTARY HISTORY OF THE SUPREME COURT, supra note 69 , at 417.

110. See, e.g., United States v. Smith, 18 U.S. (5 Wheat) 153, 161 (1820) (referring to "the law of nations, (which is part of the common law)"); United States v. Worrall, 2 U.S. (2 Dall.) 384,392 (1798) (referring to "the law of nations, which is a part of the common law of the United States"); Talbot v. Jansen, 3 U.S. (3 Dall.) 133, 161 (1795) (Iredell, J., concurring) (referring to "the common law, of which the law of nations is a part"). 
land," 111 with no suggestion that the law of nations was part of the "Laws of the United States" in a constitutional sense. ${ }^{112}$ Indeed, the Supreme Court eventually held, in an opinion by Chief Justice Marshall, that a statute granting territorial courts in Florida jurisdiction over "all cases arising under the laws and Constitution of the United States" did not extend to cases involving admiralty law, at that time a branch of the law: of nations. ${ }^{113}$ The Court explained, in terms that would seem to apply to other aspects of the law of nations, that "[a] case in admiralty does not, in fact, arise under the Constitution or laws of the United States. These cases are as old as navigation itself; and the law, admiralty and maritime, as it has existed for ages, is applied by our Courts to the cases as they arise."114 Similar equations of the law of nations with the common law can be found in the writings of prominent Founders, such as Alexander Hamilton, ${ }^{115}$ who do not appear to have believed that the law of nations was part of the "Laws of the United States." scholarly commentary also viewed the law of nations in this nonjurisdictional, common law way. ${ }^{17}$

One grand jury instruction appears at first glance to be more difficult to distinguish. In an instruction to the grand jury for the district of

111. The Nereide, 13 U.S. (9 Cranch) 288, 422 (1815).

112. The same can be said about another oft-quoted decision issued many years later, The Paquete Habana, in which the Court stated the law of nations is "part of our law." 175 U.S. 677, 700 (1900). Federal court jurisdiction in The Paquete Habana, which involved the seizure by the U.S. navy of Cuban fishing vessels, was based on the Article III and statutory provisions for admiralty cases, not on the phrase "Laws of the United States" in Article III. See id. at 680-81; see also id. at 700 (stating that international law "must be ascertained and administered by the courts of justice of appropriate jurisdiction") (emphasis added); Michael G. Collins, Before Lochner-Diversity Jurisdiction and the Development of General Constitutional Law, 74 TUL. L. REV. 1263, 1304-05 (2000) (noting that principles of general common law could form "part of our law" in that they provided a rule of decision, even though they did not provide a basis for federal question jurisdiction).

113. American Ins. Co. v. Canter, 26 U.S. (1 Pet.) 511, 545-46 (1828). For discussion of this decision, see Weisburd, supra note 86, at 30-31. See also 1 THE WORKS OF THE HONOURABLE JAMES WILSON, supra note 56, at 375 (stating that the law applied in maritime cases is "not the law of a particular country, but the general law of nations").

114. Canter, 26 U.S. at 545-46.

115. See, e.g., Hamilton, Letters of Pacificus, No. 1, supra note 65, at 34 (referring to "the laws of the land (of which the law of Nations is a part)"); Alexander Hamilton, The Defence No. $X X$ (Oct. 23 \& 24, 1795), in 19 THE PAPERS OF ALEXANDER HAMILTON 329, 341-42 (Harold C. Syrett ed., 1973) ("The common law of England which was \& is in force in each of these states adopts the law of nations... 'Tis indisputable that the customary law of European Nations is a part of the common law and by adoption that of the [United States].").

116. For a discussion of Hamilton's views regarding the relationship between Article III and the law of nations, see supra text accompanying notes 64-65.

117. See, e.g., RAWLE, supra note 65, at 104 ("The law of nations forms a part of the common law of every civilized country ...."); DUPONCEAU, supra note 88, at 3 ("The law of nations, being the common law of the civilized world ..."). 
Virginia, Chief Justice John Jay stated:

That you may perceive more clearly the Extent and objects of your Inquiries, it may be proper to observe that the Laws of the united States admit of being classed under three Heads or Descriptions

1st. all Treaties made under the authority of the united States.

2dly. The Laws of Nations

$3 \mathrm{dly}$. The Constitution, and Statutes of the united States ${ }^{118}$

This instruction obviously does include the "Laws of Nations" within its description of the "Laws of the United States." That language, along with the fact that Jay also authored Federalist No. 3, which, as noted above, contains some broad language about the law of nations, may suggest that at least Jay believed that cases arising under the law of nations arose under U.S. law for purposes of Article III.

In context, however, it seems unlikely that Jay was referring to the "Laws of the United States" in Article III. Jay was not purporting to describe to the grand jury the court's own jurisdiction under the Constitution. Rather, he was merely instructing the jury about the types of offenses that it could hear. In this context, Jay's inclusion of the law of nations within the "Laws of the United States" was probably just an explanation that the law of nations was part of the law that the United States, like other countries, could apply. As he explained in an earlier grand jury charge, "the Laws of Nations make Part of the Laws of this, and of every other civilized Nation." 119 Moreover, Jay's instruction would make no sense if read as a technical definition of "Laws of the United States" in Article III. The instruction states that the "Laws of the United States" includes treaties, the laws of nations, the Constitution, and federal statutes. Article III, however, distinguishes the Constitution and treaties from the "Laws of the United States." As a result, if Jay had

118. John Jay's Charge to the Grand Jury of the Circuit Court for the District of Virginia (May 22, 1793), in 2 THE DOCUMENTARY HISTORY OF THE SUPREME COURT, supra note 69, at 380,381 . In an earlier draft of this charge, Jay similarly wrote that, "[t]he Constitution, the Statutes of Congress, the Laws of Nations, and Treaties constitutionally made, compose the Laws of the United States." Draft of John Jay's Charge to the Grand Jury of the Circuit Court for the District of Virginia (before Apr. 22, 1793), in 2 THE DOCUMENTARY HISTORY OF THE SUPREME COURT, supra note 69 , at 359,360 .

119. John Jay's Charge to the Grand Jury of the Circuit Court for the District of New York (Apr. 12, 1790), in 2 THE DOCUMENTARY HISTORY OF THE SUPREME COURT, supra note 69, at 25, 29 (emphasis added); see also id. at 27 ("We had become a Nation [and] as such we were responsible to others for the observance of the Laws of Nations; and as our national Concerns were to be regulated by national Laws national Tribunals became necessary for the Interpretation \& Execution of them both."). 
been defining the phrase "Laws of the United States" in Article III, he would have been saying, in effect: "Article III grants the federal courts the authority to hear cases arising under the Constitution, treaties, treaties, the laws of nations, the Constitution, statutes, and treaties."

Contrary to the assertion of some scholars, ${ }^{120}$ early attorney general opinions actually undermine rather than support the claim that the law of nations was considered to be part of the "Laws of the United States" in Article III. These opinions make clear that the law of nations was viewed as a rule of decision, not an independent basis for federal court jurisdiction. Most notable in this regard is an opinion by Jefferson's attorney general, Levi Lincoln. ${ }^{121}$ In that opinion, Lincoln discussed the implications of an insult to the Spanish minister, which Lincoln described as involving "a high-handed breach of the peace, an outrageous riot, and an aggravated violation of the law of nations." 122 Lincoln stated that he could "find no provision in the Constitution, in any law of the United States, or in the treaty with Spain, which reaches the case." ${ }^{123}$ Rather, he said that the case was governed by the law of nations, which forms "part of the municipal body of each State." 124 Lincoln therefore "doubt[ed] the competency. of the federal courts, there being no statute recognizing the offence." 125 Putting aside Lincoln's doubt about federal court jurisdiction over common law offenses, the key point is that Lincoln did not consider the law of nations to be part of the "Laws of the United States," as that phrase is used in the Constitution.

Other attorney general opinions may have been more sympathetic to the possibility of federal criminal prosecutions based on the common law, but they did not suggest that the law of nations was part of the "Laws of the United States" in Article III. For example, in response to a diplomatic protest over a raid into Spanish Florida by private American citizens seeking to retrieve runaway slaves, Attorney General Charles Lee conceded that the Americans had violated the law of nations. He noted, however, that Congress had not passed an applicable law under its authority to define and punish offenses against the law of nations. As a result, Lee said that the Americans were "only liable to be prosecuted

120. See, e.g., Jordan J. Paust, Customary International Law and Human Rights Treaties Are Law of the United States, 20 MICH. J. INT'L L. 301 (1998); Stephens, supra note 34, at 416 \& n.113.

121. 5 Op. Att'y Gen. app. at 691 (1802).

122. Id. at app. 692.

123. Id.

124. Id.

125. Id. 
in our courts at common law for the misdemeanor." 126 Lee further explained that, "[t]he common law has adopted the law of nations in its full extent, and made it a part of the law of the land." ${ }^{127}$ Other early attorney general opinions contain similar statements-treating the law of nations as part of the common law rules of decision, not as part of the "Laws of the United States" referred to in the Constitution. ${ }^{128}$

In sum, although the First Congress undoubtedly expected that the federal courts would apply the law of nations in some cases as a rule of decision, it did not think of the law of nations as part of the "Laws of the United States" in Article III. Indeed, most likely, the constitutional Founders and the First Congress believed that the "Laws of the United States" were limited to federal statutes. Nor, as discussed earlier, did the First Congress view the Alien Tort Statute as creating a federal statutory cause of action. As a result, the First Congress would not have believed that cases brought under the Alien Tort Statute for torts in violation of the law of nations would fall within Article III federal question jurisdiction.

Assuming the above analysis is correct, what was the expected Article III basis for the law of nations portion of the Alien Tort Statute? One possibility is that the First Congress believed that at least some of the law of nations cases brought under the Statute would fall within Article III admiralty jurisdiction. Admiralty cases at that time frequently involved law of nations issues. Moreover, as Professor Joseph Sweeney has pointed out, ${ }^{129}$ the United States had entered into several treaties prior to 1789 in which it had promised to ensure that U.S. privateers would provide compensation for damage they caused to subjects or inhabitants of the other party, ${ }^{130}$ and it is possible that the First Congress had in mind such treaties when it referred in the Alien Tort Statute to "a

126. 1 Op. Att'y Gen. 68,69 (1797) (emphasis added).

127. Id.

128. See, e.g., 1 Op. Att'y Gen. 26, 27 (1792) (opinion by Edmund Randolph) ("The law of nations, although not specially adopted by the constitution or any municipal act, is essentially a part of the law of the land.").

129. See Sweeney, supra note 18 , at $469-70$; see also ROGERS, supra note 23 , at 119-22 (discussing Sweeney's argument).

130. See Treaty of Amity and Commerce, Feb. 6, 1778, art. 17, U.S.-Fr., reprinted in 2 TREATIES AND OTHER INTERNATIONAL ACTS OF THE UNITED STATES OF AMERICA 3, 15 (Hunter Miller ed., 1931) [hereinafter Miller]; Treaty of Amity and Commerce, Oct. 8, 1782, art. 13, U.S.Neth., reprinted in Miller, supra, at 59, 71; Treaty of Amity and Commerce, Apr. 3, 1783, art. 15, U.S.-Swed., reprinted in Miller, supra, at 123, 135; Treaty of Amity and Commerce, Sept. 10, 1785, art. 15, U.S.-Prussia, reprinted in Miller, supra, at 162, 173. 
treaty of the United States." If so, the First Congress might have viewed the Statute as an implementation of admiralty jurisdiction, because reparations in connection with privateering were governed by the law of prize, a component of admiralty law. Finally, the earliest reported cases in which the Alien Tort Statute was invoked were admiralty cases. ${ }^{131}$

Nevertheless, there are a number of reasons to believe that the First Congress was not thinking of admiralty jurisdiction when it enacted the Alien Tort Statute. Section 9 of the First Judiciary Act gave the district courts exclusive jurisdiction over admiralty cases, whereas it gave them jurisdiction concurrent with the states and circuit courts over alien tort cases. In addition, Section 9 precluded jury trials in civil admiralty cases but did not preclude jury trials in cases brought under the alien tort provision. ${ }^{132}$ Furthermore, there is no suggestion in the legislative history of the First Judiciary Act that the alien tort provision was viewed as a subset of admiralty jurisdiction, and, in fact, correspondence concerning the Act appears to distinguish between the statutory grant of admiralty jurisdiction and the alien tort provision. ${ }^{133}$ Although Professor Sweeney has hypothesized that the Alien Tort Statute was designed to ensure that state courts could exercise concurrent jurisdiction over tort claims that arose in connection with privateering (in cases in which there was no dispute over the legality of the capture), ${ }^{134}$ a generallyworded grant of jurisdiction to the federal courts would be a strange way of accomplishing that result. Moreover, as discussed below, there are other plausible reasons for the "tort only" limitation on the Statute-most notably, a disinclination to allow British creditors to use

131. See Moxon v. The Fanny, 17 F. Cas. 942 (D. Pa. 1793); Bolchos v. Darrel, 3 F. Cas. 810 (D.S.C. 1795).

132. In the Federalist Papers, Hamilton had argued that jury trials should not be available in "cases which concern the public peace with foreign nations-that is, in most cases where the question turns wholly on the laws of nations." THE FEDERALIST NO. 83, supra note 25 , at 495 , 504 (Alexander Hamilton). He further said that, "[o]f this nature, among others, are all prize causes." Id. at 504.

133. See, e.g., Letter from Oliver Ellsworth to Richard Law (Apr. 30, 1789), in 4 THE DOCUMENTARY HISTORY OF THE SUPREME COURT, supra note 70, at 382 (stating that the district courts would have "Jurisdiction in admiralty cases, smaller offences, \& some other special cases") (emphasis added); Letter from Arthur Lee to Charles Lee (May 8, 1789), in 4 THE DOCUMENTARY HISTORY OF THE SUPREME COURT, supra note 70, at 388, 388 (stating that the district courts are to have jurisdiction "in cases of Admiralty \& the law of nations") (emphasis added); Letter from Paine Wingate to Timothy Pickering (July 11, 1789), in 4 THE DOCUMENTARY HISTORY OF THE SUPREME COURT, supra note 70, at 461 ("The [district courts] are to have cognizance of maritime causes \& some other matters respecting foreigners \& the revenue.") (emphasis added). But cf. William Paterson's Notes for Remarks on Judiciary Bill (June 23, 1789), in 4 THE DOCUMENTARY HISTORY OF THE SUPREME COURT, supra note 70, at $414,415-16$ (describing the objects of the district courts' jurisdiction as admiralty, crimes, and revenue).

134. Sweeney, supra note 18 , at 482 . 
the federal courts to recover on debts owed to them by U.S. citizens. ${ }^{135}$ In any event, there is no indication from either the text of the Statute or its legislative history that it was intended to be limited to admiralty cases.

Article III also allows for jurisdiction over suits involving the federal government or individual U.S. states. ${ }^{136}$ It is unlikely, however, that the First Congress had these suits in mind in enacting the Alien Tort Statute. The sovereign immunity issues implicated by such suits would at minimum have generated discussion, if not substantial opposition. During the debates over the Constitution, Anti-Federalists like George Mason and Patrick Henry vigorously objected to Article III on the ground that it would allow the states to be sued without their consent, ${ }^{137}$ something denied by Federalists like Hamilton and Madison. ${ }^{138}$ And the Supreme Court's allowance of a suit against an unconsenting state in Chisholm v. Georgia, ${ }^{139}$ decided four years after enactment of the First Judiciary Act, generated a firestorm of controversy that resulted in the adoption of the Eleventh Amendment. ${ }^{10}$ Moreover, regardless of any uncertainty over the ability of individuals to sue states, it was widely understood in 1789 (as it is today) that the federal government could be sued only with its consent, ${ }^{141}$ and it is unlikely that the Alien Tort Statute, which does not even mention the federal government, would have been considered a sufficient manifestation of such consent. In addition, to the extent that the First Congress had in mind situations in which state or federal officials violated the law of nations, it likely would have envisioned suits against the individuals themselves, not against the government entities. ${ }^{142}$ Finally, the Judiciary Act specifically

135. See infra text accompanying notes $160-69$.

136. I address one other possible category of Article III jurisdiction-cases affecting ambassadors-in Part IV.

137. See, e.g., 10 THE DOCUMENTARY History OF THE RATIFICATION OF THE CONSTITUTION, supra note 79, at 1406-07 (remarks by George Mason during Virginia ratifying convention); $i d$. at $1422-23$ (remarks of Patrick Henry).

138. See, e.g., THE FEDERALIST No. 81, supra note 25, at 481, 487 (Alexander Hamilton) ("It is inherent in the nature of sovereignty not to be amenable to the suit of an individual without its consent."); 10 THE DOCUMENTARY HISTORY OF THE RATIFICATION OF THE CONSTITUTION, supra note 79, at 1414 (Madison) ("It is not in the power of individuals to call any State into Court."). For more extensive discussion of the ratification debates concerning this issue, see Caleb Nelson, Sovereign Immunity as a Doctrine of Personal Jurisdiction, 115 HARV. L. REV. (forthcoming 2002).

139. 2 U.S. (2 Dall.) 419 (1793).

140. See Peter W. Low \& John C. JefFries, JR., Federal Courts and the LaW of FEDERAL-STATE RELATIONS 810 (4th ed. 1998).

141. See, e.g., Cohens v. Virginia, 19 U.S. (6 Wheat.) 264, 411-12 (1821) ("The universally recognized opinion is, that no suit can be commenced or prosecuted against the United States.").

142. See, e.g., A True Federalist, INDEPENDENT CHRONICLE, Mar. 2 \& 6, 1797, reprinted in 5 THE DOCUMENTARY History OF THE SUPREME COURT OF THE UNITED STATES 629, 630 
addressed suits between states and foreign citizens elsewhere in the Judiciary Act. ${ }^{143}$

These and other points lead some commentators to conclude that the First Congress must have viewed the law of nations as part of the "Laws of the United States" in Article III. Otherwise, they reason, the First Congress would have been authorizing federal court jurisdiction over some cases that the First Congress did not itself believe were within the scope of Article III. ${ }^{144}$ There is, in fact, another possibility: the First Congress may have viewed the law of nations portion of the Alien Tort Statute (and perhaps the entire Statute) as implementing Article III alienage jurisdiction.

\section{IMPLEMENTATION OF ALIENAGE JURISDICTION}

There is substantial evidence suggesting that the First Congress believed that at least the law of nations portion of the Alien Tort Statute was an implementation of Article III alienage jurisdiction-that is, jurisdiction over "Controversies between ... the Citizens [of a state], and ... Citizens or Subjects [of a foreign state]."145 As an initial matter, this construction of the Statute is supported by the text and structure of the First Judiciary Act. The jurisdiction provided for in the Alien Tort Statute was, like the general alienage jurisdiction in Section 11, made concurrent with state court jurisdiction. By contrast, when the First Congress implemented case-denominated heads of jurisdiction in Article III, such as jurisdiction over federal crimes and jurisdiction over admiralty cases, it made the federal courts' jurisdiction exclusive. Furthermore, the jurisdiction conferred in the Alien Tort Statute was also made concurrent with that of the circuit courts. The reference to circuit court jurisdiction could only have been a reference to the alienage jurisdiction granted to the circuit courts in Section 11 (and the removal jurisdiction granted to them in Section 12). In other words, the First Congress was making clear in the alien tort provision that, when Section 11's amount in controversy requirement was satisfied, alien

(Maeva Marcus ed., 1994) ("If a foreigner is injured by a general or special act of a state, and the law of nations; or establishing treaty with his nation, or sovereign, is violated by the special or general act of a state, he has his remedy in the Court of the United States, against the person, from whose immediate doings the injuries arises ....") (emphasis added).

143. Section 13 of the Act gave the Supreme Court original but not exclusive jurisdiction over suits "between a state and ... aliens." Judiciary Act, supra note $1, \S 13$.

144. This is, in effect, Professor Dodge's argument. See Dodge, supra note 27, at 709-10. See also Burley, supra note 18 , at 468 (stating that the Alien Tort Statute "can thus be constitutionally justified only as an exercise of the federal question jurisdiction" provision of Article III).

145. U.S. CONST. art. III, $\S 2, \mathrm{cl} .1$. 
plaintiffs suing for a tort in violation of the law of nations would have the option of pursuing their claim in either the district court or the circuit court. This express linkage of the two provisions is further evidence that the Alien Tort Statute was intended to be an implementation of alienage jurisdiction.

This alienage jurisdiction construction of the Statute helps explain William Loughton Smith's description of the proposed jurisdiction of the district courts during the House debates on the Judiciary Act. In defending the proposed jurisdiction of the district courts, Smith stated:

[S]ome gentlemen are of opinion that the district court should be altogether confined to admiralty causes; while others deem it expedient that it should be intrusted with a more enlarged jurisdiction: and should in addition to admiralty causes, take cognizance of all causes of seizure on land, all breaches of impost laws, of offences committed on the high seas, and causes in which foreigners or citizens of other states are parties. The committee are now to decide between these two opinions. ${ }^{146}$

Smith thus linked Article III's diversity jurisdiction ("causes in which foreigners or citizens of other States are parties") to the district courts. And his reference to the alienage component of this diversity jurisdiction appears to be the only part of his description that would encompass the alien tort provision in Section 9, since all of his other references were addressed by other provisions in Section $9 .{ }^{147}$

Correspondence written while the First Congress was considering the Judiciary Act tends to confirm this construction. On August 10, 1789, while the House was considering the Act, Smith wrote a letter to Edward Rutledge. The letter responded to various objections made by Rutledge to the proposed Act, including, apparently, an objection that the jurisdictional provisions treated foreigners more favorably than U.S. citizens. ${ }^{148}$ In the letter, Smith described a conversation he had had the night before with Oliver Ellsworth:

I met [Ellsworth] last night \& took notice of some of your objections which he endeavored to refute. He observed that the [Constitutional] convention had in view the condition of

146. 11 DOCUMENTARY HISTORY OF THE FIRST FEDERAL CONGRESS, supra note 24, at 1349 (remarks of William Loughton Smith on Aug. 29, 1789) (emphasis added).

147. Of course, Smith's suggested linkage of the proposed district court jurisdiction with domestic diversity cases was incorrect, since the draft Judiciary Act assigned that jurisdiction only to the circuit courts. See Judiciary Act, supra note $1, \S 11$. The important point is that he was thinking of the Alien Tort Statute in terms of party-based jurisdiction, not federal question jurisdiction.

148. Historians have not found Rutledge's letter to Smith. 
foreigners when they framed the Judicial of the U. States. The Citizens were already protected by [the State] Judges \& Courts, but foreigners were not. The Laws of nations \& Treaties were too much disregarded in the several States _ Juries were too apt to be biased [against] them, in favor of their own citizens \& acquaintances: it was therefore necessary to have general Courts for causes in w[hi]ch foreigners were parties or citizens of diff[erent] States; hence arises this partiality which offends you: perhaps it may be car[ried] too far. ${ }^{149}$

This letter explicitly links the federal courts' proposed alienage jurisdiction ("causes in which foreigners were parties") with a concern about state court disregard of treaties and the law of nations. Given that the Alien Tort Statute is the only provision in the Judiciary Act referring to both treaties and the law of nations, and given that it creates a type of jurisdiction available only to foreign plaintiffs (and thus would be a prime example of the "partiality" that Rutledge was concerned about), this letter is further evidence that the Statute was, understood as an implementation of alienage jurisdiction. ${ }^{150}$

Also relevant is a letter from Edmund Pendleton to James Madison, in which Pendleton enclosed a set of questions and comments he had about the draft Judiciary Act (which he had also sent to Senator Richard Henry Lee). In this document, Pendleton asked:

[W] hat is meant by a Tort? Is it intended to include suits for the Recovery of debts, or on breach of Contracts, as a reference to the laws of Nations \& Foederal treaties seems to indicate; or does it only embrace Personal wrongs, according to it's usual legal meaning, or violations of Personal or Official privilege of foreigners? [I]n the last case it will probably be unexceptional, in the former, very inconvenient.

The next clause [relating to the proposed alienage jurisdiction of the circuit courts, which would be subject to a jurisdictional amount requirement] seems to take in the debts \& may serve to explain the former. ${ }^{151}$

149. Letter from William Loughton Smith to Edward Rutledge (Aug. 10, 1789), in 4 THE DOCUMENTARY HISTORY OF THE SUPREME COURT, supra note 70, at 496, 498-99 (emphasis added).

150. This letter has not been mentioned in most of the prior scholarship on the Alien Tort Statute. William Dodge's earlier article does refer to it briefly, see Dodge, supra note 18 , at 250 , but the article does not quote the portion of the letter referring to treaties and the law of nations, does not indicate that the letter refers to a conversation with Ellsworth, and does not link the letter to the Alien Tort Statute.

151. Letter from Edmund Pendleton to James Madison (July 3, 1789), in 4 THE 
These questions, which obviously are directed at the provision that became the Alien Tort Statute, expressly suggest a linkage between that provision and the provision in the "next clause" for general alienage jurisdiction.

Early scholarly commentary further supports this construction. In his Blackstone's Commentaries, Tucker described the law applicable in "controversies between citizens of different states; and between citizens of any state and the subjects or citizens of foreign states" as follows:

In these cases, the municipal law of the place where the cause of controversy arises, whether that be one of the United States, or Great Britain, France, Spain, Holland, Hamburg, or any other country; or the general law of merchants; or, the general law of nations according to the nature and circumstances of the case, must be the rule of decision, in whatever court the suit may be brought. ${ }^{152}$

Tucker thus understood alienage jurisdiction as a vehicle for addressing law of nations issues. Joseph Story similarly linked alienage jurisdiction to the judicial resolution of disputes involving the law of nations. ${ }^{153}$ Even more direct support for an alienage construction of the Alien Tort Statute comes from Thomas Sergeant's 1830 treatise on constitutional law and federal court practice. In that treatise, Sergeant specifically discusses the alien tort provision in Section 9 of the Judiciary Act, stating that "it would seem, such a suit for a violation of the law of nations, (if not in the admiralty,) must be against a citizen of a state: for, by the constitution, the right of an alien to sue is restricted to that case." ${ }^{\prime 154}$ Sergeant obviously understood the law of nations portion of the alien tort provision to be an implementation of alienage jurisdiction and thus as requiring, at least in non-admiralty cases, a U.S. citizen on the other side of the case. ${ }^{155}$

This construction of the Alien Tort Statute also helps explain why there was essentially no discussion of the Statute in the recorded debates of the First Congress: it was viewed as the least controversial aspect of the First Congress's implementation of alienage jurisdiction. There was,

DOCUMENTARY HISTORY OF THE SUPREME COURT, supra note 70 , at 444,446 . None of the prior articles on the Alien Tort Statute refers to this letter.

152. $1 \mathrm{ST}$. GEORGE TUCKER, supra note 28 , at app. 421.

153. See STORY, supra note $89, \S 889$, at 635 ("[T]he law to be administered in cases of foreigners is often very distinct from the mere municipal code of a state, and dependent upon the law merchant, or the more enlarged consideration of international rights and duties, in a case of conflict of the foreign and domestic laws.").

154. SERGEANT, supra note 53, at 224.

155. As discussed above, in admiralty cases, the Alien Tort Statute would typically be unnecessary, since jurisdiction would be proper under the admiralty jurisdiction statute. 
to be sure, some general controversy surrounding alienage jurisdiction. During the constitutional Founding; the Federalists had argued that the federal courts should have jurisdiction over cases involving foreign citizens because of potential bias in the state courts. ${ }^{156}$ So great was this concern that at least two proposed drafts of the Constitution-the initial Virginia plan and Hamilton's plan-would have allowed the federal courts jurisdiction over any case concerning a foreign citizen. ${ }^{157}$

In response to these arguments, the Anti-Federalists had argued that state courts could be trusted with these cases and that foreign citizens should not have greater access to federal court than in-state citizens. For example, George Mason argued during the Virginia ratification debates:

A dispute between a foreign citizen or subject, and a Virginian cannot be tried in our own Courts, but must be decided in the Federal Court. Is this the case in any other country?-Are not men obliged to stand by the laws of the country where the disputes are?-This is an innovation which is utterly unprecedented and unheard of.-Cannot we trust the State Courts with disputes between a Frenchman, or an Englishman,

156. In the Federalist Papers, Alexander Hamilton emphasized that, "[a]s the denial or perversion of justice by the sentences of courts, as well as in any. other manner, is with reason classed among the just causes of war, it will follow that the federal judiciary ought to have cognizance of all causes in which the citizens of other countries are concerned." THE FEDERALIST No. 80, supra note 25 , at 475,476 (Alexander Hamilton). At the Virginia ratifying convention, James Madison stated that "[w]e well know ... that foreigners cannot get justice done them in these [state] Courts, and this has prevented many wealthy Gentlemen from trading or residing among us." 10 THE DOCUMENTARY HISTORY OF THE RATIFICATION OF THE CONSTITUTION, supra note 79 , at 1469 . James Wilson similarly stated at the Pennsylvania convention, "is it not necessary, if we mean to restore either public or private credit, that foreigners, as well as ourselves, have a just and impartial tribunal to which they may resort?" 2 THE DOCUMENTARY HISTORY OF THE RATIFICATION OF THE CONSTITUTION, supra note 80, at 519. And William Richardson Davie remarked at the North Carolina convention that, "[i]f the rights of foreigners were left to be decided ultimately by thirteen distinct judiciaries, there would necessarily be unjust and contradictory decisions." 4 THE DEBATES IN THE SEVERAL STATE CONVENTIONS, supra note 81 , at 158 . Davie also stated: "It has been laid down by all writers that the denial of justice is one of the just causes of war. If these controversies [between U.S. citizens and foreign citizens] were left to the decision of particular states, it would be in their power, at any time, to involve the continent in a war, usually the greatest of all national calamities." Id. at 159 . See generally Kevin R. Johnson, Why Alienage Jurisdiction? Historical Foundations and Modern Justifications for Federal Jurisdiction Over Disputes Involving Noncitizens, 21 YALE J. INT'L L. 1 (1996).

157. See 1 THE RECORDS OF THE FEDERAL CONVENTION, supra note 49, at 22 (Virginia Plan); id. at 292 (Hamilton Plan); 3 THE RECORDS OF THE FEDERAL CONVENTION, supra note 47, at 626 (Hamilton Plan). The New Jersey Plan would have given the federal courts authority to hear "all Cases in which Foreigners may be interested in the Construction of any Treaty." 2 THE RECORDS OF THE FEDERAL CONVENTION, supra note 48, at 157 (emphasis added); $c f$. 1 THE RECORDS OF THE FEDERAL CONVENTION, supra note 49, at 244 (describing New Jersey plan as giving jurisdiction to hear "all cases in which foreigners may be interested, in the construction of any treaty or treaties"). 
and a citizen; or with disputes between two Frenchmen? This is disgraceful: It will annihilate your State Judiciary: It will prostrate your Legislature. ${ }^{158}$

William Grayson similarly stated during these debates that "it is extremely impolitic to place foreigners in a better position than our own citizens." 159

Probably the most significant practical concern associated with alienage jurisdiction was that it might allow British creditors to use the federal courts to enforce debts owed to them by U.S. citizens. In the preconstitutional period, states had often blocked recovery of pre-war debts owed by their citizens to British creditors. The treaty of peace between the United States and Great Britain attempted to address this problem by providing that, "creditors on either side, shall meet with no lawful impediment to the recovery of the full value in sterling money, of all bona fide debts heretofore contracted." "160 Nevertheless, some states disregarded this treaty obligation and continued to impede recovery. The Constitution addressed this and other treaty violation problems by making treaties part of the supreme law of the land and by authorizing federal court jurisdiction over cases arising under treaties. ${ }^{161}$

There was significant controversy during the Founding, however, over giving the federal courts the authority to hear suits by British creditors. Some Anti-Federalists objected to the proposed alienage jurisdiction on the ground that British creditors, like other creditors, should be required to litigate in the state courts. George Mason stated, for example:

Every one who heard me speak on the subject, knows, that I always spoke for the payment of the British debts. I wish every honest debt to be paid. Though I would wish to pay the British creditor, yet $I$ would not put it in his power to gratify private

158. 10 THE DOCUMENTARY HISTORY OF THE RATIFICATION OF THE CONSTITUTION, supra note 79 , at $1406-07$.

159. Id. at 1447.

160. Definitive Treaty of Peace, Sept. 3, 1783, U.S.-Gr. Brit., art. 4, 8 Stat. 80.

161. See FREDERICK W. MARKS, III, INDEPENDENCE ON TRIAL: FOREIGN AFFAIRS AND THE MAKING OF THE CONSTITUTION $151-52$ (1973); BRADFORD PERKINS, THE CREATION OF A REPUBLICAN EMPIRE, 1776-1865, at 61-62 (1993). For references in the Federal Convention debates to the problem of state treaty violations, see, for example, 1 THE RECORDS OF THE FEDERAL CONVENTION, supra note 49, at 18-19, 164, 316. See also THE FEDERALIST No. 22, supra note 25, at 143, 151 (Alexander Hamilton) ("The treaties of the United States under the present Constitution are liable to the infractions of thirteen different legislatures, and as many different courts of final jurisdiction, acting under the authority of those legislatures."). In the Connecticut ratification debates, Oliver Ellsworth referred to the problem of state violations of the treaty with Britain as one of the defects of the Confederation. 3 THE DOCUMENTARY HISTORY OF THE RATIFICATION OF THE CONSTITUTION 544 (Merrill Jensen ed., 1978). 
malice to our injury. ${ }^{162}$

And William Grayson expressed concern that allowing foreign creditors to sue in federal court would harm the interests of American merchants, because the foreign creditors would be able to recover on debts more quickly:

Our own State merchants would be ruined by it, because they cannot recover debts so soon in the State Courts, as foreign merchants can recover of them in the Federal Courts.... I have ever been an advocate for paying the British creditors, both in Congress and elsewhere. But here we do injury to our own citizens. ${ }^{163}$

Similar comments were expressed during the debates over the First Judiciary Act. Representative Samuel Livermore, for example, objected to "the rapidity of the course of prosecution in these courts, by which debtors would be obliged very suddenly to pay their debts at a great disadvantage."164 Representative Michael Stone "pointed out the advantages that foreigners would have over the citizens: A citizen can now get his money in three years, with an interest of 5 pr. cent. but in these courts, foreigners can get their debts in one year, with an interest of 7 or 8 pr. cent." ${ }^{\text {165 }}$ Supporters of broad federal jurisdiction, by contrast, emphasized the need to address state violations of the debt provision in the peace treaty with Great Britain. Representative Theodore Sedgwick, for example, noted that "State after state, legislature after legislature, made laws and regulations in positive opposition to the [peace treaty with Britain]; and the state judiciaries could not, or did not, decide contrary to their state ordinances."1166

As other scholars have observed, the $\$ 500$ amount in controversy limitation imposed by the First Congress on the circuit courts' jurisdiction over alienage cases may well have been a compromise in response to these competing concerns. This limitation effectively relegated small claims by British creditors to the state courts. It also could have had the effect, however, of barring essentially all alienage tort claims from the federal courts, since tort claims rarely exceeded

162. 10 THE DOCUMENTARY HISTORY OF THE RATIFICATION OF THE CONSTITUTION, supra note 79 , at 1406 .

163. Id. at 1447. Edmund Randolph responded that the remedy was to speed up adjudications in the state courts, not to eliminate the proposed federal court jurisdiction. Id. at 1455.

164. 11 DOCUMENTARY HISTORY OF THE FIRST FEDERAL CONGRESS, supra note 24, at 1375 (remarks of Samuel Livermore on Aug. 31, 1789).

165. Id. at 1378 (remarks of Michael Stone on Aug. 31, 1789).

166. Id. at 1369-70 (remarks of Theodore Sedgwick on Aug. 29, 1789). 
$\$ 500$ at that time. ${ }^{167}$ The Alien Tort Statute can be understood as addressing this problem in part, by providing for jurisdiction over certain tort cases that implicated international law. In other words, the Alien Tort Statute can be understood as restoring some of the alienage jurisdiction precluded by the amount in controversy limitation. Because it was limited to tort cases implicating international law-cases for which the argument about state bias would be particularly strong but which did not implicate the controversy over suits by British creditors $^{168}$-it would have been viewed as the least controversial aspect of the First Congress's implementation of alienage jurisdiction. ${ }^{169}$

The most significant objection to this alienage construction of the Alien Tort Statute is of course the Statute's plain language. The Supreme Court has held since the early 1800 s that the alienage clause of Article III requires a U.S. citizen in the case, yet the text of the Alien Tort Statute does not expressly require a U.S. citizen defendant. Rather, it refers to "all causes where an alien sues." There are at least two possible reasons for this textual omission, both of which are consistent with the conclusion that the First Congress viewed the Statute as an implementation of alienage jurisdiction.

First, it is possible that the First Congress believed that Article III alienage jurisdiction extended to any suit involving an alien, even suits between aliens. There are a few statements from constitutional Founders suggesting such a belief. For example, Alexander Hamilton stated in Federalist No. 80, in defending Article III, that "the federal judiciary ought to have cognizance of all causes in which the citizens of other countries are concerned." ${ }^{170}$ And George Mason, when objecting to Article III alienage jurisdiction at the Virginia ratifying convention, stated, "cannot we trust the State Courts with disputes between a Frenchman, or an Englishman, and a citizen; or with disputes between two Frenchmen?"171 Furthermore, as noted above, some of the proposed

167. See William R. Casto, The First Congress's Understanding of Its Authority over the Federal Courts' Jurisdiction, 26 B.C. L. REV. 1101, 1113 (1985).

168. Without the tort limitation, the British creditor claims arguably would have come within either the Alien Tort Statute's reference to the "law of nations" (since the law merchant was considered a component of the law of nations) or its reference to "treaties of the United States" (by virtue of the peace treaty with Britain).

169. For additional discussion of the influence of the British debts controversy on the scope of the First Judiciary Act, see Wythe Holt, "To Establish Justice": Politics, The Judiciary Act of 1789, and the Invention of the Federal Courts, 1989 DUKE L.J. 1421 (1989).

170. THE FEDERALIST No. 80, supra note 25, at 475, 476 (Alexander Hamilton).

171. 10 THE DOCUMENTARY HISTORY OF THE RATIFICATION OF THE CONSTITUTION, supra note 79, at 1406-07 (emphasis added); see also id. at 1451 (Edmund Randolph) ("I presume, therefore, that treaties and cases affecting Ambassadors, other public Ministers and Consuls, and all those concerning foreigners, will not be considered as improper subjects for a Federal 
drafts of the Constitution would have allowed jurisdiction over any case involving foreign citizens. Perhaps some members of the First Congress remembered these proposals and did not focus on the precise wording of Article III adopted at the Federal Convention. The First Judiciary Act was, after all, drafted relatively quickly and, as Edmund Randolph complained, it did not always track the language of Article III. ${ }^{172}$

On the other hand, it is difficult to understand how either the Founders or the First Congress could have understood alienage jurisdiction as extending to suits between aliens, given the relatively clear language of Article III on this point. Article III provides in relevant part that the federal judicial power shall extend "to Controversies ... between a State, or the Citizens thereof, and foreign States, Citizens or Subjects." This language seems quite clearly to require a U.S. citizen in the case. While a creative use of ellipses could yield the phrase "Controversies ... between ... foreign . . . Citizens," the same sort of edit could be made to create "Controversies... between ... Citizens," and yet no one believed that Article III diversity jurisdiction allowed for suits between citizens of the same state. As Anne-Marie Slaughter has noted, "given the clarity of the constitutional language, this entire line of argument [that the First Congress believed that the Article III alienage provision allowed for suits between aliens] strains credulity."173 While she may be overstating matters slightly, the constitutional text provides a strong argument against this interpretation of the First Congress's intent.

There is, however, another possibility that has been missed by most scholars: the First Congress may have implicitly intended that suits brought under the Alien Tort Statute would have at least one U.S. citizen on the other side of the case. To understand why this is a possibility, one must remember that Section 9 was not the only place in the First Judiciary Act where Congress referred generally to suits involving aliens. In the first clause of Section 11, which regulated the jurisdiction of the circuit courts, the Act provided that these courts "shall have original cognizance, concurrent with the courts of the several States, of all suits of a civil nature at common law or in equity,

Judiciary.") (emphasis added).

172. See Letter from Edmund Randolph to James Madison (June 30, 1789), in 4 THE DOCUMENTARY HISTORY OF THE SUPREME COURT, supra note 70, at 432 ("The jurisdiction is inartificially, untechnically and confusedly worded. Would it not have been sufficient to have left this point upon the constitution itself? Will the courts be bound by any definition of authority, which the constitution does not in their opinion warrant?"); see also 9 DOCUMENTARY HISTORY OF THE FIRST FEDERAL CONGRESS, supra note 83, at 91 (Diary of William Maclay) ("I made a remark where Elsworth in his diction had varied from the Constitution.").

173. Burley, supra note 18 , at 474 . 
where the matter in dispute exceeds, exclusive of costs, the sum or value of five hundred dollars, and ... an alien is a party." 174 Read literally, this clause would have given the circuit courts jurisdiction over suits between alien parties for non-federal claims, as long as the jurisdictional amount requirement was satisfied. Similarly, Section 12 of the Act, which governed removal of cases from state courts, referred to "a suit ... commenced in any state court against an alien." 175 . Again, the literal terms of this provision would have included suits between aliens.

Nevertheless, there is evidence to suggest that Oliver Ellsworth, the chief draftsman of the First Judiciary Act, believed that the general reference to alien party suits in Section 11 implicitly required a U.S. citizen in the case. In writing to Judge Richard Law of Connecticut, Ellsworth proceeded to describe the proposed Judiciary Act, which he had been working on for several weeks. In describing the jurisdiction of the circuit courts, Ellsworth stated that they would have jurisdiction over "controversies between foreigners \& citizens." referring generally in Section 11 to suits involving aliens, it appears that Ellsworth, consistent with Article III, had in mind suits in which the other party would be a U.S. citizen. ${ }^{177} \mathrm{His}$ failure to note this explicitly in the language of the draft would not have been out of character with his writing style. As one biographer noted, "Ellsworth ... possessed a peculiar style of condensed statement." other members of the First Congress shared Ellsworth's understanding. In an early letter, Fisher Ames sent John Lowell a sketch of the proposed judicial system, "which has been proposed and is the subject of conversation of three or four persons only." 179 In the letter, Ames stated that there would be a jurisdictional amount requirement for cases "arising between a foreign and a citizen," clearly suggesting that he understood that alienage diversity jurisdiction would involve a U.S.

174. Judiciary Act, supra note $1, \S 11$ (emphasis added).

175. Id. $\S 12$ (emphasis added).

176. Letter from Oliver Ellsworth to Richard Law (Apr. 30, 1789), in 4 THE DOCUMENTARY HISTORY OF THE SUPREME COURT, supra note 70, at 382, 382.

177. For additional discussion of this point, see Dennis J. Mahoney, A Historical Note on Hodgson v. Bowerbank, 49 U. CHI. L. REV. 725 (1982). See also DAVID P. CURRIE, THE CONSTITUTION IN CONGRESS: THE FEDERALIST PERIOD, 1789-1801, at 51 (1997) ("In light of the care exercised elsewhere in the statute to avoid exceeding the limits implicit in Article III's enumeration, the Supreme Court may well have been right to conclude that in this instance as well Congress had no intention of going beyond the constitutional provision.").

178. WILLIAM GARROTT BROWN, THE LIFE OF OLIVER ELLSWORTH 41 (1905); see also 9 DOCUMENTARY HISTORY OF THE FIRST FEDERAL CONGRESS, supra note 83, at 360 (Diary of William Maclay) (describing Ellsworth, in connection with a draft statute concerning consuls and vice-consuls, as "all powerful \& eloquent in Debate" but "a miserable Draughtsman").

179. Letter from Fisher Ames to John Lowell (Mar. 15, 1789), in 4 THE DOCUMENTARY HISTORY OF THE SUPREME COURT, supra note 70, at 367. 
citizen in the case. ${ }^{180}$

This is also how the Supreme Court construed Section 11 of the Act in several early decisions. In Mossman v. Higginson, decided in 1800, the Court stated that Section 11 "can, and must, receive a construction, consistent with the constitution." "181 Thus, while acknowledging that Section 11 referred generally to any suit "where ... an alien is one party," the Court construed this language as referring implicitly to situations in which an alien is one party "but a citizen is the other."182 Importantly, in this decision and others, the Court did not view this as a difficult issue. In Montalet v. Murray, decided in 1807, the Court stated that it "was unanimously of opinion that the courts of the United States have no jurisdiction of cases between aliens." 183 And, in Hodgson $v$. Bowerbank, decided in 1809 , the Court, in a very short opinion by Chief Justice Marshall, stated as follows: "Turn to the article of the constitution of the United States, for the statute cannot extend the jurisdiction beyond the limits of the constitution."184 Thus, it was patently clear to the early Supreme Court that Article III alienage jurisdiction required a U.S. citizen in the case, and the Court assumed that this is what the First Congress had in mind when it referred generally in Section 11 to suits involving aliens. ${ }^{185}$

180. Id. Similarly, in a letter to Oliver Ellsworth commenting on the proposed Judiciary Act, Robert Livingston, a lawyer in New York, appeared to understand that alienage jurisdiction extended to controversies "between foreign[ers] \& Citizens." Letter from Robert R. Livingston to Oliver Ellsworth (June 24, 1789), in 4 THE DOCUMENTARY HISTORY OF THE SUPREME COURT, supra note 70 , at 420,420 . In 1790, at the request of the House of Representatives, Attorney General Edmund Randolph prepared a comprehensive report concerning the proper structure and jurisdiction of the federal courts. In his report, Edmund Randolph included within the proposed jurisdiction of the district courts "controversies ... . between the citizens of a state, and foreign citizens or subjects." Report of the Attorney General to the House of Representatives (Dec. 27, 1790), in 4 THE DOCUMENTARY HISTORY OF THE SUPREME COURT, supra note 70, at 127, 141. Thus, it appears that Randolph envisioned that alienage jurisdiction would involve a U.S. citizen in the case. Randolph's report contains no equivalent of the Alien Tort Statute, and, although it recommends jurisdiction over cases arising under treaties, it does not mention any jurisdiction based specifically on the law of nations.

181. 4 U.S. (4 Dall.) 12, 14 (1800).

182. Id. One of the justices involved in this decision was William Paterson, who had assisted in the drafting of the First Judiciary Act.

183. 8 U.S. (4 Cranch) 46, 47 (1807).

184. 9 U.S. (5 Cranch) 303,304 (1809). Of course, courts had the constitutional power to hear cases between aliens when there was an independent Article III basis for jurisdiction, such as admiralty jurisdiction. Even in those cases, however, the Marshall Court expressed some doubt about the propriety of exercising such jurisdiction in the absence of the consent of the parties. See Mason v. Ship Blaireau, 6 U.S. (2 Cranch) 239, 264 (1804).

185. As Dennis Mahoney has explained, when read in context with the other decisions, Hodgson did not hold Section 11 unconstitutional, as some scholars have assumed, but rather simply construed it as not extending to suits between aliens. See Mahoney, supra note 177, at 730. 
The alien tort clause in Section 9 can similarly be construed as referring implicitly to suits brought by aliens against U.S. citizens. Understood this way, the alien tort clause is a subset of the First Congress's general grant of alienage diversity jurisdiction in Section 11, but without a jurisdictional amount requirement. This special treatment of cases involving torts in violation of international law is not surprising, for the reason mentioned above: the First Congress probably viewed such cases as a component of alienage jurisdiction particularly appropriate for federal court jurisdiction. Moreover, because they were limited to torts, these cases would not have implicated the concern about giving the federal courts broad jurisdiction over suits by British creditors. ${ }^{186}$

This construction of the Statute is consistent with the law of international responsibility in the late 1700 s. Nations were responsible under the law of nations to punish and compensate offenses committed by their citizens; although there might also have been circumstances under which nations had an obligation to punish offenses by foreign citizens committed in their territory, nations were not themselves liable for the damages caused by such foreign citizens. Vattel explained in his influential international law treatise, for example, that "[a] sovereign who refuses to repair the evil done by one of his subjects, or to punish the criminal, or, finally, to deliver him up, makes himself in a way an accessory to the deed, and becomes responsible for it." 187 Blackstone similarly stated in his Commentaries that "where the individuals of any state violate this general law [of nations], it is then the interest as well as duty of the government under which they live, to animadvert upon them with a becoming severity, that the peace of the world may be maintained." 188 The views of these commentators were well known, and

186. In addition, as Professor Mark Weisburd has noted, the circuit courts for each judicial district were originally scheduled to meet only twice a year. District courts, by contrast, were scheduled to meet four times a year. As a result, the Alien Tort Statute allowed a class of particularly sensitive alienage cases to be addressed more expeditiously by the federal courts. See Weisburd, supra note 19 , at 1225-26.

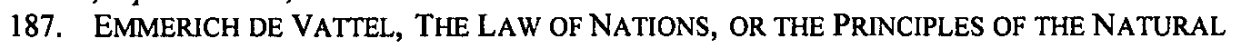
LAW, APPLIED TO THE CONDUCT AND TO THE AFFAIRS OF NATIONS AND OF SOVEREIGNS 137 (1758) (Charles G. Fenwick trans., 1916) (emphasis added).

188. 4 BLACKSTONE, supra note 56, at 68 (emphasis added). Professor Slaughter has argued that the Alien Tort Statute "was a straightforward response to what the Framers understood to be their duty under the law of nations." Burley, supra note 18, at 464. In defending the Filartiga line of cases, however, Professor Slaughter makes no attempt to tie the scope of the Statute to the United States' duties under the law of nations, either in 1789 or today. In neither time period has the United States had a duty under international law to provide a civil remedy for torts committed by foreign citizens against other foreign citizens outside the United States. Cf. Rogers, supra note 18, at 47 (arguing that the First Congress intended to limit the Alien Tort Statute to tortious acts, "which, if unaddressed, would result in international legal responsibility on the part of the United 
heavily relied upon, in the pre-constitutional and Founding periods. ${ }^{189}$

The law of international responsibility helps explain a resolution issued by the Continental Congress in 1781, which some scholars have suggested might have been a precursor to the Alien Tort Statute. ${ }^{190}$ In that resolution, Congress called on the states to punish various conduct in violation of international law: "the violation of safe conducts or passports"; the "commission of acts of hostility against such as are in amity, league or truce with the United States, or who are within the same, under a general implied safe conduct"; "the infractions of the immunities of ambassadors and other public ministers"; and the "infractions of treaties and conventions to which the United States are a party." "191 The resolution explained that this was a list only of the most obvious offenses against the law of nations, and ones concerning which "public faith and safety requir[e] that punishment should be coextensive with such crimes." 192

As indicated by the above quotations, the bulk of the 1781 resolution was focused on the need for state criminal punishment. The congressional committee that prepared this resolution explained in its report that there was concern that "the scheme of criminal justice in the several states does not sufficiently comprehend offenses against the law of nations." ${ }^{193}$ At the end of the resolution, however, Congress recommended that states authorize certain civil damages actions. As reported in the Journals of the Continental Congress, the recommendation was that the states "authorize suits to be instituted for damages by the party injured, and for compensation to the United States for damage sustained by them from an injury done to a foreign power

States").

189. For Blackstone's influence, see Dennis R. Nolan, Sir William Blackstone and the New American Republic: A Study of Intellectual Impact, 51 N.Y.U. L. REV. 731 (1976). See also, e.g., 10 THE DOCUMENTARY HISTORY OF THE RATIFICATION OF THE CONSTITUTION, supra note 79, at 1382 (statement by James Madison at the Virginia ratifying convention that, "I will refer you to a book which is in every man's hand-Blackstone's Commentaries."). For Vattel's influence, see DANIEl GEORGE LANG, FOREIGN POLICY IN THE EARLY REPUBLIC: THE LAW OF NATIONS AND THE BALANCE OF POWERS 15-16 (1985). See also, e.g., Letter from Benjamin Franklin to Charles Dumas (Dec. 19, 1775), in 2 THE REVOLUTIONARY DIPLOMATIC CORRESPONDENCE OF THE UNITED STATES 64 (Francis Wharton ed., 1889) (stating that a copy of Vattel's treatise had "been continually in the hands of the members of our [Continental] Congress now sitting").

190. Burley, supra note 18, at 476-78; Casto, supra note 18, at 490-91; Dodge, supra note 18, at 226-29. There is no mention of this resolution, however, in the debates or correspondence concerning the Judiciary Act.

191. 21 JOURNALS OF THE CONTINENTAL CONGRESS $1136-37$ (Gaillard Hunt ed., 1912) (Nov. 23, 1781).

192. Id. at 1137 .

193. Id. at 1136 . The members of the committee were Edmund Randolph, James Duane, and John Witherspoon. See id. 
by a citizen." ${ }^{1144}$ Scholars have emphasized this language in particular as a possible precursor to the Alien Tort Statute. Importantly, however, this language refers to "injury done to a foreign power by a citizen" and thus may not have been intended to encompass alien-versus-alien suits. In other words, the 1781 resolution, if it is a precursor to the Alien Tort Statute, may provide further support for an alienage jurisdiction construction of the Statute. ${ }^{195}$

Some scholars have dismissed this possible reading of the resolution, arguing that the resolution's syntax makes clear that the "by a citizen" reference limits only suits by the federal government for reimbursement, not "suits ... by the party injured." 196 These scholars, however, have relied on the version of the resolution that was published in the Journals of the Continental Congress. This published version differs from the handwritten version reported out of the committee in a number of small respects, most notably in its use of commas. With respect to the civil damages recommendation, the handwritten version (apparently in Edmund Randolph's handwriting) provided: "That it be farther recommended, to authorize suits to be instituted for damages by the party injured, and for compensation to the United States for damage, sustained by them from an injury, done to a foreign power by a citizen." 197 With these additional commas, the last phrase- - "done to a

194. Id. at 1137.

195. See also Collins, supra note 21, at $654 \mathrm{n} .21$ (making similar point). A possible piece of contrary evidence is the enactment by Connecticut in 1782, perhaps in response to the 1781 resolution, of an "Act to Prevent Infractions of the Law of Nations." See 4 THE PUBLIC RECORDS OF THE STATE OF CONNECTICUT FOR THE YEAR 1782, at 156-57 (Leonard Woods Labaree ed., 1942). In addition to providing for criminal sanctions for certain violations of the law of nations, the Connecticut statute stated: "That if any Injury shall be offered and done by any Person or Persons whatsoever, to any foreign Power, or to the Subjects thereof, either in their Persons or Property, by means whereof any Damage shall or may any ways arise, happen or accrue, either to any such foreign Power, to the said United States, to this State, or to any particular Person; the Person or Persons offering or doing any such Injury, shall be liable to pay and answer all such Damages as shall be occasioned thereby." Id. at 157. This provision does not appear to be limited to torts committed by U.S. citizens. Of course, unlike the First Judiciary Act, this provision was not enacted against the backdrop of Article III of the Constitution. It also differed from the later Alien Tort Statute in that it was not limited to violations of the law of nations or treaties. Nevertheless, it is worthy of note, especially since Oliver Ellsworth, who later played a lead role in drafting the First Judiciary Act, was a member of the Continental Congress and the upper house of the Connecticut legislature when this statute was enacted. See William R. Casto, Correspondence, 83 AM. J. INT'L L. 901,903 (1989).

196. See Casto, supra note 18, at 499 n.179; Dodge, supra note 18, at 228; cf. Scott A. Rosenberg, Note, The Theory of Protective Jurisdiction, 57 N.Y.U. L. REV. 933, 1016-18 (1982) (noting that the 1781 resolution "seems to bear out the suggestion that Congress primarily envisioned suits against citizens of the United States," but nevertheless arguing that the Alien Tort Statute should be interpreted more broadly).

197. See Papers of the Continental Congress (Microfilm) M247 r35 p197, originally catalogued as No. 28, folio 197. 
foreign power by a citizen"-can more easily be read to modify the entire recommendation, not just the portion concerning compensation to the United States. This appears to be how early constitutional law commentators, including Joseph Story, construed the resolution. ${ }^{198}$

Moreover, this reading is consistent with the drafting committee's explanation of its proposal. The report provides three justifications for the resolution: First, "[t]hat the scheme of criminal justice in the states does not sufficiently comprehend offenses against the law of nations." 199 Second, that the United States would find it difficult to disavow a violation of international law "by a citizen of the United States" if "regular and adequate punishment shall not have been provided against the transgressor." ${ }^{200}$ Third, that there would be instances "in which, for the avoidance of war, it may be expedient to repair out of the public treasury injuries, committed by individuals," and that "the author of those injuries should compensate the damage out of his private fortune."201 The second and third justifications confirm that the committee had in mind violations of international law by U.S. citizens. The second justification expressly refers to U.S. citizens. The third justification refers to situations in which the U.S. government would potentially feel compelled to pay the claims and subsequently seek reimbursement. Yet, as the text of the resolution itself makes clear, the U.S. government would feel compelled to pay the claims only in situations in which there was an "an injury done to a foreign power by a citizen." As noted above, this view was consistent with the law of international responsibility at that time. ${ }^{202}$

An alienage jurisdiction construction of the Alien Tort Statute also fits well with Federalist No. 80, the Federalist Paper that, as discussed above, focuses specifically on the proposed jurisdiction of the federal courts. As noted, Hamilton began that essay by outlining six categories of cases that should be heard in the federal courts. The fourth category involves those cases "which involve the PEACE of the CONFEDERACY,

198. See SERGEANT, supra note 53, at 16 (stating that the resolution called upon states "to authorize suits for damages by the party injured, and for compensation to the United States for damages sustained by them from an injury done to a foreign power, by a citizen"); 3 JOSEPH STORY, COMMENTARIES ON THE CONSTITUTION OF THE UNITED STATES $§ 1654$, at 523 n.3 (1833) (stating that the resolution called upon states to "authorize suits for damages by the party injured, and for compensation to the United States, for damages sustained by them, from an injury done to a foreign power by a citizen").

199. 21 JOURNALS OF THE CONTINENTAL CONGRESS, supra note 191, at 1136.

200. Id. (emphasis added).

201. Id.

202. See also Rosenberg, supra note 196, at 1016-17 \& n.414 (documenting recurring concern of the Continental Congress with violations by U.S. citizens of the law of nations concerning neutrality). 
whether they relate to the intercourse between the United States and foreign nations or to that between the States themselves." ${ }^{203}$ In discussing this category, Hamilton argues that "the federal judiciary ought to have cognizance of all causes in which the citizens of other countries are concerned." $204 \mathrm{He}$ also argues that, although one could imagine a distinction between foreign citizen cases "arising upon treaties and the laws of nations" and those "which may stand merely on the footing of the municipal law," even the municipal law cases could raise international law or foreign relations issues, and that it would in any event be difficult to separate out international law from municipal law cases. ${ }^{205}$ As a result, he argues that "it is by far most safe and most expedient to refer all those [cases] in which [foreign citizens] are concerned to the national tribunals." 206

One could read Hamilton as asserting here that all cases involving foreign citizens should be heard in the federal courts, even cases between foreign citizens involving non-federal claims. The problem with this reading, as with the similar possible reading of Section 11 of the Judiciary Act, is that it assumes a fairly severe misconstruction of the terms of Article III. Hamilton was of course aware of the language of Article III in writing Federalist. No. 80-indeed, he quotes it accurately later in that essay and states that " $[t]$ his constitutes the entire mass of the judicial authority of the Union.."207 $\mathrm{He}$ also goes on to describe accurately the alienage jurisdiction clause as requiring a U.S. citizen on one side of the case.

An alternate reading of Hamilton's discussion of his fourth category is that when he is referring to suits involving foreign citizens, he has in mind suits between foreign citizens and U.S. citizens, not suits purely between foreign citizens. Under this reading, Hamilton is stating that Article III allows the federal courts to have jurisdiction over all cases between foreign citizens and U.S. citizens, regardless of whether these cases concern international law or municipal law. Such a statement would of course be accurate, since Article III allows the federal courts to hear all controversies between foreign citizens and U.S. citizens,

203. THE FeDERALIST No. 80 , supra note 25 , at 475,475 (Alexander Hamilton).

204. Id. at 476.

205. Id. at 476-77. The First Judiciary Act can be seen as implementing the very distinction that Hamilton argued against, by imposing a jurisdictional amount requirement for alienage cases involving municipal law but not for alienage cases involving treaties and the law of nations. $C f$. Burley, supra note 18, at 466 (" $[\mathrm{I}] \mathrm{t}$ is easy to hypothesize that the drafters of the First Judiciary Act, unable to implement [Hamilton's] recommendation in full, tried to use the alien tort provision in section 9 to draw precisely this distinction.").

206. THE FEDERALIST NO. 80, supra note 25, at 475, 477 (Alexander Hamilton).

207. Id. at 479 . 
without regard the nature of the claims. This reading of Federalist No. 80 is supported by the fact that, when Hamilton does specifically discuss the diversity clauses, including the alienage clause, he expressly ties those clauses back to his discussion of the fourth category of cases. ${ }^{208}$

An alienage jurisdiction construction of the Alien Tort Statute is also consistent with the first Attorney General opinion discussing the Statute. In 1794, American citizens assisted a French fleet in attacking and plundering the British colony at Sierra Leone. ${ }^{209}$ In response to British complaints about the incident, Attorney General William Bradford prepared an opinion explaining the legal remedies that were available in U.S. courts to address these "acts of hostility committed by American citizens." 210 Bradford indicated that criminal prosecution of the individuals was uncertain, because, among other things, U.S. courts would not exercise criminal jurisdiction over conduct that originated or took place in a foreign country. But Bradford stated that "there can be no doubt" that those who were injured in this incident could pursue a civil suit in U.S. courts, "jurisdiction being expressly given to these courts in all cases where an alien sues for a tort only, in violation of the laws of nations, or a treaty of the United States." ${ }^{211}$ This opinion obviously envisions a suit brought by alien plaintiffs against American citizens, something within Article III alienage jurisdiction. There is no suggestion in the opinion that the Alien Tort Statute could be used to address similar acts of hostility committed by foreign citizens, such as the French citizens involved in the attack. ${ }^{212}$

Finally, an alienage jurisdiction construction of the Statute fits at least reasonably well with the pre-Filartiga case law. Many but not all of the reported cases before Filartiga in which the Alien Tort Statute was invoked involved suits by aliens against U.S. citizens. In almost all of the alien-versus-alien suits, the courts declined to entertain the claims-because, for example, the courts concluded that no genuine law of nations violation had been alleged-and thus did not address whether the Statute extended to suits between aliens. One of the two pre-

208. See id. at 481 .

209. For discussion of the incident, see CHRISTOPHER FYFE, A HISTORY OF SIERRA LEONE 59-61 (1962), and JOHN PETERSON, PROVINCE OF FREEDOM: A HISTORY OF SIERRA LEONE 1787-1870, at 31 (1969).

210. 1 Op. Att'y Gen. 57, 58 (1795).

211. Id. at 59 .

212. See also Fourth Annual Address of President George Washington (Nov. 6, 1792), in 1 A COMPIlation of THE Messages and PaPers of THE PRESIDENTS 117, 120 (James D. Richardson ed., 1897) (annual address by President Washington to Congress identifying "aggressions by our citizens on the territory of other nations" as "infractions of the law of nations") (emphasis added). 
Filartiga decisions upholding jurisdiction under the Statute, however, did involve a suit between aliens. In Bolchos v. Darrel, Bolchos, a French captain, captured an enemy Spanish ship as a prize and brought it into a South Carolina port. ${ }^{213}$ On board the vessel were several slaves who had been mortgaged to an English citizen. The English citizen's agent, Darrel, seized and sold the slaves. Bolchos brought suit against Darrel, arguing that the slaves had been part of the prize to which he was entitled. The suit was brought first in a South Carolina state court, which dismissed the case because it concluded that the case fell within the exclusive admiralty jurisdiction of the federal courts. The suit was then re-filed in the federal district court for the district of South Carolina. That court noted that it had some initial doubts about whether it had admiralty jurisdiction over the case, since Darrel's seizure of the slaves had been made on land. But the court concluded that, "as the original cause arose at sea, everything dependent on it is triable in the admiralty [jurisdiction]."214 The court further stated, without explanation, that jurisdiction was also proper by virtue of the alien tort clause in Section 9 of the First Judiciary Act. This brief reference to the Alien Tort Statute, in a single district court decision, does not by itself provide significant evidence that the First Congress intended the Statute to reach alien-versus-alien suits. ${ }^{215}$

In sum, the text and structure of the First Judiciary Act, and the correspondence surrounding it, suggest that Congress viewed at least the law of nations portion of the Alien Tort Statute as an implementation of

213. 3 F. Cas. 810 (D.S.C. 1795) (No. 1,607).

214. Id. at 810 .

215. In the only other pre-Filartiga decision upholding jurisdiction under the Alien Tort Statute, one of the defendants was a U.S. citizen. See Adra v. Clift, 195 F. Supp. 857, 859 (D. Md. 1961). Professor Dodge also relies on the early district court decision, Moxon v. The Fanny, 17 F. Cas. 942 (D. Pa. 1793) (No. 9,895). See Dodge, supra note 27, at 699. In Moxon, a French schooner, manned by U.S. citizens, seized a British ship in U.S. waters. The owners of the British ship brought an admiralty "libel" action directly against the seized ship. The court concluded that it lacked jurisdiction over the suit, because it did not believe that it was proper for the courts of a neutral country to decide on the propriety of a capture made in its territory by one foreign enemy against another. Moxon, $17 \mathrm{~F}$. Cas. at $947-48$. The court noted in passing that jurisdiction also would be improper under the Alien Tort Statute because the action, which sought restitution of property as well as damages, was not for a "tort only." Id. The fact that the court there thought that jurisdiction was improper under the Alien Tort Statute on one ground does not show that the court would have found jurisdiction to be proper on some other ground. Moreover, unlike an admiralty libel action, an Alien Tort Statute action presumably would have been directed against the U.S. citizens on board the French schooner, in which case there would have been Article III alienage jurisdiction. 
Article III alienage jurisdiction. This conclusion is not contradicted - and, indeed, is actually strengthened-by other historical materials that have been linked to the Statute. As a result, either the First Congress thought that Article III alienage jurisdiction extended to suits between aliens, or it implicitly intended to limit the Alien Tort Statute to suits involving a U.S. citizen defendant (at least in nonadmiralty cases). There is evidence to support both of these possibilities, but the weight of the evidence tends to support the latter interpretation.

\section{SUITS BY AMBASSADORS}

The possibility that the Alien Tort Statute is limited to suits against U.S. citizens has been disregarded by most scholars because they have assumed that one of the purposes of the Statute was to allow foreign ambassadors to sue in federal court for torts committed against them on U.S. soil, even when the tort is committed by another foreign citizen. ${ }^{216}$ Scholars have made this assumption because of two famous preconstitutional incidents involving violations of the law of nations with respect to ambassadors. A close examination of these incidents and the constitutional and statutory responses to them, however, shows that they have little if any relevance to the Alien Tort Statute.

By way of background, it is important to understand the state of international law in the late 1700 s concerning the treatment of ambassadors and other public ministers. As Blackstone explained, ambassadors had immunity from criminal prosecution: if an ambassador violated the laws of a host country, the ambassador could be sent home, but, at least as a general matter, the ambassador could not be prosecuted. ${ }^{217}$ Ambassadors also had immunity from civil suits, such

216. See Casto, supra note 18, at 491-94; Dodge, supra note 18, at 229-30; Randall, supra note 18, at 26; Rogers, supra note 18, at 54-55. Anne-Marie Burley (now Anne-Marie Slaughter) disavows a connection between ambassadorial protection and the Alien Tort Statute in the first half of her article, see Burley, supra note 18, at 469-74, but she appears to embrace such a connection in the second half of her article, see $i d$. at 476-77. See also Tel-Oren v. Libyan Arab Republic, 726 F.2d 774, 813-14 (1984) (Bork, J., concurring) (assuming a connection between the Alien Tort Statute and ambassadorial protection). The U.S. Department of Justice made the same assumption in an amicus curiae brief it submitted to the Ninth Circuit. In that brief, the Department argued that the Statute should not be construed to cover torts committed by foreign citizens outside the United States. Largely on the basis of the Marbois incident discussed below, however, the Department assumed for the sake of argument that the Statute extended to some suits between aliens. See Brief of Amicus Curiae the United States of America at 10-11, Trajano v. Marcos, 878 F.2d 1439 (9th Cir. 1989) (Nos. 86-2448, 86-2449, 86-2496, 86-15039, 87-1706, 87-1707). I must confess that I too assumed a connection between ambassadorial protection and the Alien Tort Statute before researching this article. See Bradley \& Goldsmith, supra note 21, at 360 .

217. 1 BLACKSTONE, supra note 55, at 246-47. 
that "neither an embassador, nor any of his train or comites, can be prosecuted for any debt or contract in the courts of that kingdom wherein he is sent to reside." ${ }^{.18}$ This civil immunity became settled in England, Blackstone explained, after a controversial incident in 1708, when a Russian ambassador was arrested in London for nonpayment of debts. The British parliament responded to the incident by enacting an ambassadorial protection statute. This statute (which, as discussed below, was largely duplicated by the First Congress 82 years later) nullified proceedings directed against foreign ambassadors, gave ambassadors and their domestic servants immunity from arrest and attachment of their property, and provided for criminal punishment of those attempting to sue or prosecute ambassadors. ${ }^{219}$

Blackstone also lists assaults on ambassadors as one of the individual offenses against the law of nations. ${ }^{220}$ The Swiss publicist, Emmerich de Vattel, elaborated on this point in his treatise on the law of nations. An act of violence against an ambassador, says Vattel, is not an ordinary crime but "a crime of State and an offense against the Law of Nations." ${ }^{221}$ Vattel further explained that the person of the ambassador was considered inviolable, which meant not only that the ambassador had immunity from arrest, but also that the host country was under an obligation to protect the ambassador from violence. "To receive a minister in his representative capacity," states Vattel, "is equivalent to promising to give him the most particular protection and to see that he enjoys all possible safety."222 Vattel also explained that an ambassador's residence is inviolable and should be kept "safe from all insult.".223

These rights and privileges of ambassadors were at issue in two important pre-constitutional controversies. On May 17, 1784, a French citizen, Charles Julian de Longchamps, insulted Francois de Barbee Marbois, Consul General of France and Secretary of the French Legation, at Marbois's residence in Philadelphia. ${ }^{224}$ The next day, Longchamps confronted Marbois on a public street, threatened him, and struck his cane, forcing Marbois to defend himself. The French minister immediately asked the President of Pennsylvania's executive council, John Dickinson, to have Longchamps arrested. The minister also notified the Continental Congress of the incident, explaining that " $[t]$ he

218. Id. at 247.

219. See Diplomatic Privileges Act, 7 Ann., c. 12 (1708) (Eng.).

220. 4 BLACKSTONE, supra note 56, at 68.

221. VATTEL, supra note 187 , at 371 .

222. Id.

223. Id. at 394.

224. See generally Alfred Rosenthal, The Marbois-Longchamps Affair, 63 THE PENNSYLVANIA MAG. 294 (1939). 
offender is not yet apprehended; and it is possible he has fled into some other State in the confederacy."225 The minister requested that Congress recommend to Pennsylvania and the other states that they "take effectual measures, conformable to the laws of nations, for the solemn reparation of the offence committed on the person of the Consul General.."226

In response, Congress immediately passed a resolution recommending that the states offer a reward of $\$ 500$ for Longchamps' apprehension, to be reimbursed by the federal government, and that the states direct their officers to arrest him. ${ }^{227}$ At about the same time, Pennsylvania's executive council sent a letter to the Continental Congress informing it of the matter and noting that Pennsylvania authorities had obtained custody of Longchamps. The council further stated that

[w]e should be much pleased to be favoured with the sentiments of Congress upon this business, being extremely desirous that our proceedings may correspond with their judgment, and to testify our determined resolution, with all our powers, to maintain the dignity of the United States, to preserve the public repose, to assert the law of nations, and to manifest our entire regard for the representatives of the sovereignty of the union. ${ }^{228}$

In response, the Continental Congress stated that it "highly approve[d]" of the sentiments expressed in the council's letter. ${ }^{229}$

At first, the French minister, as well as the Dutch minister, Pieter J. Van Berckel, expressed concern that Pennsylvania might not adequately address the incident. They even threatened to leave Pennsylvania if "full satisfaction" were not provided. Dickinson repeatedly assured the ministers that Pennsylvania would do everything it could to vindicate the law of nations. Similarly, Congress assured the French minister that it was "well convinced of the necessity of securing to all foreign Ministers, resident in these States, every privilege and right to which they are entitled by usage or the laws of nations." 230

225. Letter from Le Chevalier de la Luzerne to the Continental Congress (May 20, 1784), in DEP'T OF STATE, 1 THE DIPLOMATIC CORRESPONDENCE OF THE UNITED STATES OF AMERICA 89 (1837).

226. Id.

227. See 27 Journals of THE CONTINENTAL CONGRESS 478 (Gaillard Hunt ed., 1928) (May 29, 1784).

228. Id. at 503 (1784) (quoting a letter from John Dickinson to the Continental Congress dated May 28, 1784).

229. Id. at 503-04; see also id. at 565 (stating that the sentiments expressed by the council "meet the fullest approbation of the Committee of the States").

230. 1 THE DIPLOMATIC CORRESPONDENCE OF THE UNITED STATES, supra note 225, at 90. 
After briefly escaping from police custody, Longchamps was tried before the Pennsylvania Supreme Court. Pennsylvania's executive council hired James Wilson to assist the Pennsylvania attorney general (William Bradford) in carrying out the prosecution. Longchamps was ultimately convicted of violating the law of nations, which the Pennsylvania Supreme Court described as "form[ing] a part of the municipal law of Pennsylvania."231 Explaining to Longchamps that it was "the interest as well as duty of the government, to animadvert upon your conduct with a becoming severity," the Pennsylvania court sentenced him to approximately two years in jail, fined him one hundred French crowns, and required that he post a bond guaranteeing his good behavior for seven years. The court declined, however, to turn him over to French authorities, notwithstanding a demand to this effect from the French minister.

For some time thereafter, Marbois persisted in demanding that Longchamps be turned over to France. In response, John Jay, the Secretary for Foreign Affairs, submitted a report to the Continental Congress in which he concluded that the demands were premature, since Longchamps was serving his sentence in Pennsylvania. ${ }^{232}$ Congress subsequently directed Jay to inform Marbois that Congress was still considering the matter, and to explain "the difficulties that may arise on this head from the nature of a federal union in which each State retains a distinct and absolute sovereignity in all matter not expressly delegated to Congress leaving to them only that of advising in many of those cases in which other governments decree. ${ }^{.233}$ Congress also issued a resolution calling on the states "to pass laws for the exemplary punishment of such persons as may in future by violence or by insult attack the dignity of sovereign powers in the person of their ministers or servants," and directing Jay to draft model legislation to be sent to the states. ${ }^{234}$ Marbois subsequently dropped his extradition request but "expressed a Wish that Congress would pass Resolutions asserting the Rights of Ministers \&c. and recommending to the States to pass Laws to punish Violations of them in an exemplary Manner."235 Congress directed John Jay to draft the resolution Marbois requested. ${ }^{236}$ It does

231. Respublica v. De Longchamps, 1 U.S. (1 Dall.) 111, 114 (1784).

232. See 28 JOURNALS OF THE CONTINENTAL CONGRESS 314-15 (John C. Fitzpatrick ed., 1933) (Apr. 27, 1785); 1 THE DIPLOMATIC CORRESPONDENCE OF THE UNITED STATES, supra note 225 , at 115 .

233. 28 JOURNALS OF THE CONTINENTAL CONGRESS, supra note 232, at 314.

234. Id. at 315 .

235. 29 JOURNALS OF THE CONTINENTAL CONGRESS 598 (John C. Fitzpatrick ed., 1933) (Aug. 2, 1785).

236. See id. at 655 (Aug. 24, 1785) ("Resolved, That the Secretary to the United States for 
not appear, however, that Jay ever did so. ${ }^{237}$

For a number of reasons, it is unlikely that this incident is the genesis of the Alien Tort Statute. This incident concerned only a criminal prosecution and a requested extradition, not the ability to bring a private tort suit. Marbois apparently never attempted to bring such a suit against Longchamps, and the need for such a suit was never mentioned in connection with the incident. Furthermore, contrary to the suggestion of some scholars, neither the Continental Congress nor foreign nations appear to have been particularly unhappy with the way Pennsylvania handled the criminal prosecution. Pennsylvania acted quickly to obtain custody of Longchamps, and its courts ultimately convicted him of the offense. The only major foreign complaint appears to have been directed at Pennsylvania's decision not to extradite Longchamps to France, a decision not opposed by the Continental Congress and which, in any event, had nothing to do with the ability to bring a private tort suit in a U.S. court. Finally, to the extent that the Marbois incident highlighted the lack of national government control over the prosecution of offenses against ambassadors, or even over the prosecution of law of nations offenses more generally, the obvious remedy would have been to give the national government this prosecutorial authority, not to create federal court jurisdiction over private tort suits.

The other ambassadorial protection incident that has been described by some scholars as leading to the enactment of the Alien Tort Statute is one that occurred in December 1787, during the time that the states were considering the proposed Constitution. A New York police officer, John Wessel, entered the house of the Dutch minister, Van Berckel (the same Van Berckel who had expressed concern during the Marbois incident), and arrested one of his domestic servants. Van Berckel immediately complained of the incident to John Jay. ${ }^{238}$ At Jay's request, New York's mayor, James Duane, investigated the incident and had the police officer arrested. Duane also explained to Jay that

I need not remind you, sir, that neither Congress nor our internal Legislature have yet passed any act respecting a breach of the privileges of Ambassadors; so that the nature and degree of punishment depend on the common law, the crime on the law of

the department of foreign affairs be, and he is hereby directed to report the draft of an act to be recommended to the legislatures of the respective states, for punishing infractions of the laws of nations, and more especially for securing the privileges and immunities of public Ministers from foreign powers.").

237. Casto, supra note 18, at 493 n.144.

238. 3 DEP'T OF STATE, THE DIPLOMATIC CORRESPONDENCE OF THE UNITED STATES OF AMERICA 443 (1837); see also 34 JOURNALS OF THE CONTINENTAL CONGRESS 24-25 (Roscoe R. Hill ed., 1937) (Feb. 1, 1788). 
nations, which is a breach of the common law. ${ }^{239}$

On the same day, Jay reported to Congress that "the federal Government does not appear to ... be vested with any judicial Powers competent to the Cognizance and Judgment of such cases. ${ }^{240}$ The police officer was subsequently convicted of violating the law of nations, as adopted by New York common law, and sentenced to three months in jail. This conviction and sentence apparently resolved the matter to Van Berckel's satisfaction.

Even if the Van Berckel incident were relevant to the First Congress's intent in enacting the Alien Tort Statute, it would not contradict an alienage jurisdiction construction of the Statute, since the wrongdoer in the incident was a U.S. citizen. In any event, although closer in time to the enactment of the Alien Tort Statute, the Van Berckel incident seems no more connected to that Statute than the earlier Marbois incident. The issue, once again, was criminal punishment of offenses against ambassadors, not the ability to bring a private tort action. In addition, to the extent that Jay or the Continental Congress perceived inadequacies in the state of the law, those inadequacies presumably related to the protection of ambassadors, not the protection of aliens in general, yet the Alien Tort Statute covers suits by any alien.

To be sure, it is quite possible that the constitutional Founders had incidents like the Marbois incident in mind. In his opening remarks to the Federal Convention, Edmund Randolph noted that one of the defects in the Articles of Confederation was that the national government "could not cause infractions of treaties or of the law of nations, to be punished," and he observed that "[i]f the rights of an ambassador be invaded by any citizen it is only in a few States that any laws exist to punish the offender." ${ }^{241}$ In a subsequent public letter, Randolph noted that in "the constitutions, and laws of the several states ... the law of nations is unprovided with sanctions in many cases, which deeply affect public dignity and public justice. ${ }^{.242} \mathrm{He}$ further observed that the Continental Congress did not have the express authority "to remedy these defects," and that, as a result, the confederacy might be "doomed to be plunged into war, from its wretched impotency to check offenses

239. 3 THE DiPLOMATIC CORRESPONDENCE OF THE UNITED STATES, supra note 238, at 447 .

240. 34 JOURNALS OF THE CONTINENTAL CONGRESS, supra note 238, at 111 (Mar. 25, 1788).

241. 1 THE RECORDS OF THE FEDERAL CONVENTION, supra note 49, at 19,25 .

242. A Letter of His Excellency Edmund Randolph, Esquire, on the Federal Constitution (Oct. 10, 1787), in 8 THE DOCUMENTARY HISTORY OF THE RATIFICATION OF THE ConstiTution 262, 263 (John P. Kaminski \& Gaspare J. Saladino eds., 1988). 
against this law. ${ }^{243}$ James Madison similarly remarked at the Federal Convention that, under the Articles of Confederation, the country was unable to "prevent those violations of the law of nations \& of Treaties which if not prevented must involve us in the calamities of foreign wars." 244 In the Federalist Papers, Madison further stated that the Articles of Confederation were deficient because they "contain no provision for the cases of offenses against the law of nations; and consequently leave it in the power of any indiscreet member to embroil the Confederacy with foreign nations." 245

These statements suggest that the Founders were concerned about the lack of national government power to punish offenses against the law of nations, including offenses committed against ambassadors. The Founders addressed this concern, however, in ways unrelated to the Alien Tort Statute. Most importantly, they gave Congress the power to "define and punish... Offences against the Law of Nations." that power, the national government would no longer be forced to rely on the states to punish violations of the law of nations, such as the violations at issue in the Marbois and Van Berckel incidents. ${ }^{247}$ In addition, the Constitution included within the original jurisdiction of the Supreme Court "all Cases affecting Ambassadors, other public Ministers and Consuls."248 Thus, to the extent that the Marbois and Van Berckel incidents suggested a need for a federal judicial forum for cases involving ambassadors, the Constitution provided for such a forum-in the highest court in the land. As Hamilton explained in the Federalist Papers,

[a]ll questions in which [ambassadors] are concerned are so directly connected with the public peace, that, as well for the preservation of this as out of respect to the sovereignties they represent, it is both expedient and proper that such questions should be submitted in the first instance to the highest judicatory

243. Id.

244. I THE RECORDS OF THE FEDERAL CONVENTION, supra note 49, at 316.

245. THE FEDERALIST No. 42, supra note 25, at 264, 265 (James Madison).

246. U.S. CONST. art. I, § 8, cl. 10.

247. For discussions of the "define and punish" clause, see Charles D. Siegal, Deference and Its Dangers: Congress' Power to "Define . . Offenses Against the Law of Nations," 21 VAND. J. TRANSNAT'L L. 865 (1988); Beth Stephens, Federalism and Foreign Affairs: Congress's Power to "Define and Punish . . Offenses Against the Law of Nations," 42 WM. \& MARY L. REV. 447 (2000); Howard S. Fredman, Comment, The Offenses Clause: Congress' International Penal Power, 8 Colum. J. TRANSNAT'L L. 279 (1969); Zephyr Rain Teachout, Note, Defining and Punishing Abroad: Constitutional Limits on the Extraterritorial Reach of the Offenses Clause, 48 DUKE L.J. 1305 (1999).

248. U.S. CONST. art. III, $\S 2$, cl. 2. 
of the nation. ${ }^{249}$

The First Congress similarly addressed cases involving ambassadors in provisions unrelated to the Alien Tort Statute. In Sections 9 and 11 of the First Judiciary Act, it gave the district and circuit courts jurisdiction over "all crimes and offences cognizable under the authority of the United States." Regardless of whether the First Congress intended this phrase to encompass common law crimes-a matter of significant dispute - at minimum it allowed federal court jurisdiction over offenses committed in violation of federal statutory law, including statutory law enacted pursuant to Congress's power to define and punish offenses against the law of nations. And, in its first general crimes statute, enacted in 1790, Congress used its define and punish power to enact a number of protections for ambassadors. ${ }^{250}$ This portion of the statute (which was very similar to the 1708 British ambassadorial protection statute discussed above) provided that any writ or process providing for the arrest, imprisonment, or attachment of property of any ambassador or other public minister, or their domestic servant, would be "null and void." ${ }^{251}$ It further provided that anyone suing for or prosecuting any such writ or process "shall be deemed violaters of the laws of nations, and disturbers of the public repose, and imprisoned not exceeding three years."252 These provisions would have covered the circumstances of the Van Berckel incident. Finally, in a provision that would have covered the circumstances of the Marbois incident, Congress provided:

That if any person shall violate any safe-conduct or passport duly obtained and issued under the authority of the United States, or shall assault, strike, wound, imprison, or in any other manner infract the law of nations, by offering violence to the person of an ambassador or other public minister, such person so offending, on conviction, shall be imprisoned not exceeding three years, and fined at the discretion of the court. ${ }^{253}$

In addition to giving the federal courts the authority to hear criminal cases involving affronts to ambassadors, Congress gave the Supreme Court, in Section 13 of the Judiciary Act, exclusive original jurisdiction over all "suits or proceedings against ambassadors, or other public ministers, or their domestics, or domestic servants, as a court of law can

249. THE FEDERALIST No. 81, supra note 25, at 481,487 (Alexander Hamilton).

250. See An Act for the Punishment of Certain Crimes Against the United States, ch. IX, $\S \S$ 25-28, 1 Stat. 112, 117.18 (1790). Congress had already enacted criminal provisions in connection with other legislation, such as legislation concerning duties on goods.

251. Id. $\S 25$.

252. Id. $\S 26$.

253. Id. $\S 28$. 
have or exercise consistently with the law of nations," and it gave the Court non-exclusive original jurisdiction over "all suits brought by ambassadors, or other public ministers, or in which a consul, or vice consul, shall be a party."254 Section 13 thus mandated that suits against ambassadors be heard in the Supreme Court, but it gave ambassadors the option of bringing a suit either in the Supreme Court or another court (including, presumably, a state court). Thus, to the extent that the Marbois and Van Berckel incidents suggested a need for federal jurisdiction over civil suits brought by ambassadors, such jurisdiction was provided for, outside the context of the Alien Tort Statute. ${ }^{255}$

*** $*$

For such an important and widely-made claim, it is surprising how little evidence there is to support a connection between the Alien Tort Statute and the Marbois and Vàn Berckel incidents. The only evidence, in fact, is that these incidents occurred prior to the enactment of the First Judiciary Act, and that the conduct in those incidents would have constituted a tort in violation of the law of nations. Given the contrary evidence discussed above, these incidents should not be given significant weight in discerning the original meaning of the Alien Tort Statute. Although the First Congress may not have intended to preclude ambassadors from using the Alien Tort Statute, it does not appear to have had ambassador suits in mind when enacting the Statute, especially a hypothetical suit between a foreign ambassador and another foreign citizen. ${ }^{256}$ As discussed above, the lack of a connection between the Alien Tort Statute and the ambassadorial protection incidents (especially the Marbois incident) makes it easier to accept the proposition that the First Congress intended to limit the Alien Tort Statute to suits involving at least one U.S. citizen, and that the First Congress therefore did not attempt to exceed the bounds of Article III in enacting that Statute. ${ }^{257}$

254. Section 9 also gave the district courts exclusive jurisdiction over "suits against consuls and vice-consuls." See Judiciary Act, supra note $1, \S 9$.

255. It is thus incorrect to state, for example, that without the Alien Tort Statute, "aliens like Marbois ... would have been forced to bring their civil suits in state court, unless they could meet the narrow requirements for alienage jurisdiction." Dodge, supra note 18, at 236. As the Judiciary Act made clear, they could bring their civil suits in the U.S. Supreme Court.

256. Professor Collins's discussion of suits by ambassadors may reflect a misunderstanding of my argument. I am not arguing, as he appears to assume, that the First Congress "meant to exclude [ambassadors and other officials] from the class of those who could sue under the statute." Collins, supra note 21 , at 675 . I am simply arguing that the First Congress did not have ambassadorial protection in mind when it enacted the Statute.

257. In writing about the Alien Tort Statute in 1986, Professor Casto referred to an 1804 


\section{CONCLUSION}

The Alien Tort Statute might not be such a "legal Lohengrin" after all. By considering this statute against the backdrop of Article III of the Constitution, we can draw certain conclusions about the First Congress's likely intent. The First Congress obviously intended to give alien plaintiffs access to federal court in certain cases involving international law. Contrary to modern claims, however, the First Congress did not understand the law of nations portion of the Alien Tort Statute to be an implementation of federal question jurisdiction. The law of nations was not understood in 1789 to be part of the "Laws of the United States" referred to in Article III, and the Alien Tort Statute was not viewed as creating a federal statutory cause of action for violations of the law of nations. Instead, the First Congress probably saw the Alien Tort Statute, like Section 11 of the Judiciary Act, as an implementation of Article III alienage jurisdiction. If so, the First Congress either believed that this jurisdiction encompassed suits between aliens or, more likely, believed that the Alien Tort Statute would be used, at least outside the admiralty context, for suits against U.S. defendants.

The implications of this history for modern cases brought under the Alien Tort Statute depend on a number of complex factors beyond the scope of the Article. First, such implications depend on whether judges, when applying a statute, should be bound by Congress's original intent in enacting that statute. I will not attempt to address that issue here, other than to note that originalism is probably more widely accepted in the statutory as opposed to constitutional context, at least among judges. Congress, after all, always has the power to amend a statute if it needs updating, but it is much more difficult to amend the Constitution. Furthermore, even though it may be proper for courts to play a countermajoritarian role in applying the Constitution, it is more difficult to justify such a role when applying legislative enactments.

The post-Erie federal common law also complicates matters. As discussed in Part II, the constitutional Founders and First Congress probably understood the "Laws of the United States" in Article III to be limited to federal statutory law. The modern Supreme Court, however, has held that post-Erie federal common law is part of the "laws of the

Attorney General Opinion, which suggests that an ambassador could "prosecute[]" an action in federal district court relating to the kidnapping of one of the ambassador's domestic servants. See 1 Op. Att'y Gen. 141, 147 (1804). Professor Casto construed that Opinion as implicitly referring to the Alien Tort Statute. See Casto, supra note 18, at 504 n.208. He recently informed me, however, that he has reconsidered his interpretation of that Opinion and that he now construes it as referring only to the possibility of a criminal action. 
United States" referred to in the federal question jurisdiction statute. ${ }^{258}$ Almost a fortiori, this holding suggests that post-Erie federal common law is part of the "Laws of the United States" referred to in Article III. If the law of nations is today part of the post-Erie federal common law, a proposition I have disputed in other writings, ${ }^{259}$ then suits brought under the Alien Tort Statute for violations of the law of nations would fall within the federal courts' Article III federal question jurisdiction. Whether the scope of the Statute should be determined in this anachronistic fashion is, again, beyond the scope of this Article.

If nothing else, courts may find that the original history of the Alien Tort Statute provides a basis for judicial restraint in the face of everexpanding claims about the Statute's scope. The text of the Statute is notable for the many important issues it does not address. It does not tell us, for example, what conduct violates the law of nations, the remedies available for these violations, or whether claims brought under the Statute are subject to various restrictions such as statutes of limitation, exhaustion requirements, the forum non conveniens doctrine, and official immunities. In part because of its silence on these issues, human rights advocacy groups and plaintiffs' lawyers have sought to persuade courts in recent years to adopt increasingly expansive interpretations of the Statute. The fact that the First Congress had a much narrower understanding of the Statute may at least suggest that courts should await additional legislative direction before allowing the Statute to be expanded any further. The gap between the First Congress's original understanding and modern practice may also suggest that it is time for the Supreme Court to turn its attention to this once obscure jurisdictional provision.

258. See Illinois v. City of Milwaukee, 406 U.S. 91, 100 (1972). Writing for the Court, Justice Douglas explained that the "natural meaning" of the word "laws" in the statute included "claims founded upon federal common law as well as those of a statutory origin." Id.

259. See Curtis A. Bradley \& Jack L. Goldsmith, Customary International Law as Federal Common Law: A Critique of the Modern Position, 110 HARV. L. REV. 815 (1997); Curtis A. Bradley \& Jack L. Goldsmith, Federal Courts and the Incorporation of International Law, 111 HARV. L. REV. 2260 (1998). For the possibility that federal courts could treat the law of nations today as part of "general law," as opposed to federal or state law, compare Bradley \& Goldsmith, Customary International Law as Federal Common Law, supra, at 853-54 (rejecting such a possibility as precluded by Erie), with Ernest A. Young, Sorting Out the Debate Over Customary International Law, 42 VA. J. INT'L L. 365 (2002) (arguing for this possibility), and Weisburd, supra note 86 (essentially the same, although not using the label "general law"). If the law of nations were treated today as general law, it presumably would have the same status in U.S. courts that general law had before Erie. As a result, it would not be considered part of the "Laws of the United States" referred to in Article III, and Alien Tort Statute cases could constitutionally be brought in the federal courts only if the cases fell within some other category of Article III jurisdiction, such as alienage jurisdiction. 
* * * 